\title{
A meta-analysis of working memory impairments in autism spectrum disorders
}

Ya Wang ${ }^{1 \#^{*}}$, Yi-bing Zhang ${ }^{2 \#}$, Lu-lu Liu ${ }^{1,3 \#}$, Ji-fang Cui ${ }^{4}$, Jing Wang ${ }^{2}$, David H K Shum ${ }^{5}$, Therese van Amelsvoort ${ }^{6}$, Raymond C K Chan ${ }^{1}$

${ }^{1}$ Neuropsychology and Applied Cognitive Neuroscience Laboratory, CAS Key Laboratory of Mental Health, Institute of Psychology, Beijing, China

${ }^{2}$ Department of Youth Work, China Youth University for Political Sciences, Beijing, China

${ }^{3}$ University of Chinese Academy of Sciences, Beijing, China

${ }^{4}$ National Institute of Education Sciences, Beijing, China

${ }^{5}$ Menzies Health Institute Queensland and School of Applied Psychology, Griffith University, Gold Coast, Australia

${ }^{6}$ Department of Psychiatry and Psychology, Maastricht University, Maastricht, the Netherlands

\# These authors contributed equally to this work.

*Correspondence should be addressed to: Ya Wang, Institute of Psychology, Chinese Academy of Sciences, 16 Lincui Road, Chaoyang District, Beijing 100101, China, Email: wangyazsu@gmail.com, Tel: 8610-64881148, Fax: 8610-64872070. 


\section{Acknowledgements}

This work was supported by the National Science Foundation of China (31571130, and 81571317); Youth Innovation Promotion Association Funding of Chinese Academy of Sciences (Y1CX131003); Key Laboratory of Mental Health, Institute of Psychology, Chinese Academy of Sciences (113000C136); the Beijing Training Project for the Leading Talents in S \& T (Z151100000315020), and the CAS/SAFEA International Partnership Programme for Creative Research Teams (Y2CX131003). 


\section{A Meta-analysis of working memory impairments in autism spectrum disorders}

\section{Abstract}

Autism spectrum disorders (ASD) are characterized by executive dysfunction, and working memory (WM) comprises one core component of executive function. Many studies have investigated WM impairments in individuals with ASD, however, a conclusive agreement has not been reached. The present study provided a meta-analytic review of WM impairments in individuals with ASD and evaluated potential moderating variables of this problem. Twenty-eight studies were included in this study, and the participants comprised 819 individuals with ASD and 875 healthy controls. A significant WM impairment (Cohen's $d=-0.61$ ) was identified in the individuals with ASD, however, this impairment was not associated with age. Results of moderation analyses showed that (a) spatial WM was more severely impaired than verbal WM and (b) the component of cognitive processing (maintenance vs. maintenance plus manipulation) did not affect the severity of WM impairments. These findings suggest that WM is impaired in individuals with ASD and may have implications for interventions related to WM impairments in these individuals.

Keywords: working memory, autism spectrum disorders, meta-analysis, moderator 


\section{Introduction}

Autism Spectrum Disorders (ASD), a spectrum of neurodevelopmental disorders, are characterized by persistent deficits in social interaction and communication and restricted repetitive and stereotyped patterns of behavior (American Psychiatric Association, 1994). Many theories have been proposed to explain the prominent deficits of ASD, including the theory of mind deficit theory, which states that individuals with ASD do not have the ability to mentalize or cannot infer the mental states of other individuals (Baron-Cohen, Leslie, \& Frith, 1985); the weak central coherence theory, which states that individuals with ASD tend to process parts or detailed information of objects or situations rather than their global meaning (Frith, 1989); and the executive dysfunction theory, which states that most abnormalities of individuals with ASD are related to executive dysfunction (Hill, 2004). Of these theories, the executive dysfunction theory accounts for many of the non-social aspects of autism and is the only theory that acknowledges both the cognitive and motor aspects of ASD (Rajendran \& Mitchell, 2007).

Executive function is a broad construct, and there is no one unified definition. In general, it is agreed that executive function represents an umbrella term for several abilities, such as planning, initiation, shifting, working memory (WM), problem solving, monitoring, and self-control (Chan, Shum, Toulopoulou, \& Chen, 2008; Jurado \& Rosselli, 2007). Studies have demonstrated that executive functions are impaired at different age periods in individuals with ASD throughout development (from early childhood to adulthood) (Luna, Doll, Hegedus, Minshew, \& Sweeney, 
2007). WM is an important component of executive function, and many researchers have investigated WM impairments in individuals with ASD (Boucher, Mayes, \& Bigham, 2012; Kercood, Grskovic, Banda, \& Begeske, 2014). WM is important for daily functioning, for example, when we have a conversation with a partner, we need to remember what was said by the partner and what we are going to say when the partner is speaking. It has been demonstrated that WM impairments are associated with learning disabilities (Alloway \& Gathercole, 2006) and many problems associated with behavioral regulation and cognitive impairments, such as sustaining attention and abstract thinking (Kercood et al., 2014; Ozonoff \& McEvoy, 1994). Furthermore, WM impairments have been reported to be related to communication and socialization deficits (Gilotty et al., 2002; Oliveras-Rentas et al., 2012) and restrictive and repetitive symptoms (Lopez et al., 2005; Sachse et al., 2013) in individuals with ASD. Thus, it is important to obtain a clearer and better understanding of WM impairments in individuals with ASD.

WM is the process by which information is maintained in an activated, on-line state to support the temporal continuity of behavior (Baddeley, 1986). Inconsistent findings have been reported regarding WM impairments in individuals with ASD. For example, studies have demonstrated that individuals with ASD were impaired in WM tasks (Bennetto, Pennington, \& Rogers, 1996; Bodner, Beversdorf, Saklayen, \& Christ, 2012). However, other studies have failed to identify WM impairments in individuals with ASD compared with typically developing individuals (Morsanyi \& Holyoak, 2010; Ozonoff \& Strayer, 2001). One possible reason for these inconsistent results is that 
these studies did not differentiate verbal and spatial WM according to Baddeley's model (Baddeley, 1986). Baddeley et al.'s (1986) model of WM suggests that WM is composed of a central executive component and two storage systems, namely, the visuospatial sketchpad and the phonological loop. The visuospatial sketchpad processes visual information, whereas the phonological loop processes speech-based information. In studies conducted that examined the two systems separately in individuals with ASD, a differential impairment has been identified; for example, an intact verbal WM ability and a defective spatial WM ability (Cui, Gao, Chen, Zou, \& Wang, 2010; Williams, Goldstein, Carpenter, \& Minshew, 2005).

In addition, different tasks that are considered measures of WM may involve different components of cognitive processing, that is, maintenance and manipulation. Some of these tasks only involve the maintenance component, whereas other tasks involve both maintenance and manipulation components. For example, digit span forward and digit span backward are both considered measures of WM, however, the former assesses maintenance, whereas the latter assesses both maintenance and manipulation (Redick \& Lindsey, 2013). Studies have suggested that WM impairments in individuals with ASD may be related to components of cognitive processing or cognitive load (Goldberg et al., 2005; Williams, Goldstein, \& Minshew, 2006). The present study aimed to systematically review and quantitatively analyze WM impairments in individuals with ASD and determine whether a differential impairment in verbal and spatial WM exists in these individuals. We were also interested in whether individuals with ASD exhibit different WM impairments 
relating to different components of cognitive processing. Understanding whether individuals with ASD have a WM impairment and which factors affect this problem is important for early intervention and cognitive training.

The nature and extent of WM impairments in individuals with ASD also depends on other factors, such as age, IQ, and diagnostic criteria. Happé and colleagues have demonstrated that young individuals with ASD made more errors in spatial WM tasks compared with typically developing controls, whereas there was no difference in older individuals with ASD (Happé, Booth, Charlton, \& Hughes, 2006). Most individuals with ASD exhibit an intellectual disability, and intellectual ability may be related to WM functions in these individuals. Finally, while Luna et al. (2007) identified WM impairments in individuals with ASD, Edgin and Pennington (2005) did not identify this type of impairment in individuals with ASD. Luna et al. (2007) proposed that this discrepancy might have occurred because in their study they used the Autism Diagnostic Observation Schedule (ADOS; Lord et al., 1989) as well as the Autism Diagnostic Interview-Revised (ADI-R; Lord, Rutter, \& Le Couteur, 1994), whereas Edgin and Pennington (2005) only used the ADI-R. This approach adopted by Luna et al. might have resulted in a more conservative diagnosis for their study. The ADI-R and the ADOS represent the gold standard in the diagnosis of ASD (Filipek et al., 1999). Therefore, we were also interested in whether there would be a differential WM impairment between individuals with ASD diagnosed with only the ADI/ADOS criteria, individuals diagnosed with only the Diagnostic and Statistical Manual of Mental Disorders (DSM)/International Classification of Disease (ICD), and individuals 
diagnosed with both the ADI/ADOS and DSM/ICD.

In summary, the current study aimed to provide a meta-analysis of WM impairments in individuals with ASD. In addition, we aimed to evaluate the potential moderators on WM impairments in these individuals. Specifically, we investigated several variables, such as WM type (verbal vs. spatial), component of cognitive processing (maintenance vs. maintenance plus manipulation), diagnostic criteria (ADI/ADOS, DSM/ICD, vs. both ADI/ADOS and DSM/ICD), age, and IQ.

\section{Methods}

\subsection{Literature search}

A literature search was conducted to identify published studies that examined WM impairments in individuals with ASD. The databases searched included Elsevier, PsychINFO, Springer, and ProQuest Psychology Journals. The key words used comprised "autism + working memory" and "Asperger + working memory", and the search period was from 1986 to June 1, 2014. We also searched for additional articles based on the reference lists of the identified articles.

We identified 499 potentially relevant articles from the literature search. Twenty-eight studies were ultimately included in the current meta-analysis, and all studies met the following criteria: a) patients were diagnosed with the DSM (American Psychiatric Association, 1987, 1994, 2000) ${ }^{1}$, ICD (Word Health Organization, 1992), ADI/ADI-R (Le Couteur et al., 1989; Lord et al., 1994) or

\footnotetext{
${ }^{1}$ DSM-III-R, DSM-IV, and DSM-IV-TR were used by the reviewed studies.
} 
ADOS/ADOS-Generic (Lord et al., 2000; Lord et al., 1989); b) studies included at least one WM task (WM tests measure maintenance or maintenance plus the manipulation of information in the short term); and c) studies reported sufficient data to enable the calculation of effect sizes. For the studies that met criteria a) and b) but did not include sufficient data to calculate the effect size, we approached the authors of the articles to obtain the relevant data ${ }^{2}$. The process of article selection is described in Figure 1. In total, we identified 499 papers. Following duplicate removal, 304 papers remained. Following the exclusion of papers that did not include a control group (as the effect size could not be calculated) or did not include a WM task, 32 papers remained. Following the exclusion of one paper that investigated siblings of ASD individuals and did not include individuals with ASD, one paper that did not have sufficient data to calculate the effect size, one paper that included WM performance as a matching variable (individuals with ASD and controls were matched for WM performance), and one paper that only used ADOS (not a standalone diagnostic instrument) for a diagnosis ${ }^{3}, 28$ papers were included in the final analysis.

\section{INSERT FIGURE 1 HERE}

\subsection{Data extraction}

For each study, we recorded the following variables: (1) name of the first author and year of publication; (2) age, IQ and number of participants in the ASD and

\footnotetext{
${ }^{2}$ We sent two requests, and data were provided by the author(s) of one article.

${ }^{3}$ One reviewer suggested that the ADI-R is based on the DSM criteria and is considered a gold standard in ASD diagnosis, the ADOS is not an appropriate standalone diagnostic instrument, thus one study relied solely on the ADOS for diagnosis (Eack et al., 2013) was excluded from the meta-analysis. Including this study would not change the results.
} 
healthy control groups; (3) name and type (verbal or spatial) of the WM tasks used; (4) component of cognitive processing (maintenance vs. maintenance plus manipulation) included in the WM tasks; (5) diagnostic criteria used: only ADI/ADOS, only DSM/ICD, or both ADI/ADOS and DSM/ICD; and (6) mean and SD of measures for each WM task for the two groups of participants (Table 1).

\section{INSERT TABLE 1 HERE}

It should be noted that one study (Yi et al., 2014) included two control groups (age-matched and ability-matched), whereas all other studies used age-matched participants as healthy controls. Thus, we only coded the age-matched control group for these studies in the current meta-analysis.

\subsection{Data analysis}

To quantify the magnitude of the difference between the individuals with ASD and the normal controls for each WM measure, we computed effect sizes (Cohen's $d$ ) based on the means and $S D$ s reported in each study using the Comprehensive Meta Analysis program (CMA Version 2.0) (http://www.meta-analysis.com/index.php). Most effect sizes were calculated based on accuracy, however, reaction time was used to calculate the effect sizes in two studies (Cui et al., 2010; Koshino et al., 2008). Many studies used several WM tasks; therefore, more than one effect size was calculated for these studies. According to the aims of each analysis, when several 
effect sizes were computed in one study, an unweighted average effect size was calculated and used. We subsequently conducted further analyses based on the sample sizes and averaged effect sizes with the CMA. When conducting the meta-analysis, the $Q$ statistic was used to assess the homogeneity of the studies. The publication bias was estimated via the fail-safe $\mathrm{N}$. The fail-safe $\mathrm{N}$ represents the number of additional studies with a null effect (effect size $=0$ ) needed to increase the $p$ value of the meta-analysis to greater than 0.05 (Rosenthal, 1979). If the fail-safe $\mathrm{N}$ is substantially larger than the number of studies included in the meta-analysis, it suggests that the difference tested does exist.

To summarize, we conducted the following analyses: 1) To examine the overall WM impairment of ASD, we analyzed the overall effect size of all studies (using a mean effect size for studies that had more than one effect size). Two studies (Cui et al., 2010; Koshino et al., 2008) measured WM performance using both reaction time and accuracy. Individuals with ASD only exhibited an impairment in the reaction time. Thus, for these two studies, we only used reaction time to calculate the effect sizes. For all effect sizes, we set the direction as negative, which indicates a better performance in the healthy controls. 2) Moderator analyses were conducted on the following variables: the diagnostic criteria (only ADI/ADOS, only DSM/ICD, vs. both ADI/ADOS and DSM/ICD); the WM type (verbal vs. spatial); the component of cognitive processing (maintenance vs. maintenance plus manipulation); and the WM load (1-back vs. 2-back) as a form of cognitive load. In addition, meta-regression analyses were conducted on the WM impairment using 
age and the IQ of the individuals with ASD as predictors.

\section{Results}

\subsection{Overall WM impairment in individuals with ASD}

Twenty-eight studies that included 819 individuals with ASD and 875 healthy controls were identified to compare the WM performance between the two groups. Several studies included two or three experiments or two independent samples; thus, 32 contrasts were undertaken. The $Q$ value for the heterogeneity analysis was significant $(Q=72.94, p<0.001)$, which indicated that the results of these studies were heterogeneous. The pooled effect size (Cohen's $d$ ) for all WM tasks was -0.61 (95\% confidence interval $=-0.78 \sim-0.46 ; Z=-7.66, p<0.001)$, which indicated that individuals with ASD exhibited a WM impairment to a medium to large degree. The results of the publication bias analysis indicated that 1137 studies with negative results were needed to reject this significant finding. This number is substantially larger than the number of studies included in the present analysis. Thus, the likelihood of publication bias is not high (Borenstein, Hedges, Higgins, \& Rothstein, 2009).

\subsection{Moderator analysis}

\subsubsection{Effect of diagnostic criteria}

Regarding diagnostic criteria, we excluded three studies in which individuals with ASD were not diagnosed with the same criteria (Poirier et al., 2011, exp1/2/3; Gabig, 
2008; Geurt et al., 2012). As a result, 27 contrasts were undertaken. Nine of the 27 contrasts used only the ADOS/ADI criteria or both, 10 of the 27 contrasts used only the DSM/ICD criteria and eight contrasts used both the ADI/ADOS and DSM/ICD. The results demonstrated that the individuals diagnosed with ASD with only the ADOS/ADI criteria exhibited a small to medium effect sized impairment $(d=-0.38)$; the individuals diagnosed with ASD using only the DSM/ICD criteria exhibited a small to medium effect sized impairment $(d=-0.47)$; and the individuals diagnosed with ASD using both criteria exhibited an impairment with medium to large effect sizes ( $d$ $=-0.68)$ (Table 2 and Figure 2). The results of the moderator analysis indicated that the effect of diagnostic criteria was significant for WM impairment $(Q=8.17, p=$ 0.017). Furthermore, pairwise comparisons demonstrated that the studies that used both the ADI/ADOS and DSM/ICD criteria exhibited a larger WM impairment compared with the studies that used only the ADI/ADOS criteria $(Q=6.72, p=0.010)$ and studies that used only the DSM/ICD criteria $(Q=4.93, p=0.026)$.

\section{INSERT TABLE 2 HERE}

\section{INSERT FIGURE 2 HERE}

\subsubsection{Effect of WM type}

To investigate whether individuals with ASD are differentially impaired in verbal and spatial WM tasks, we conducted a moderator analysis on the WM type. In one study (viz., Crane et al., 2011), the authors did not report the scores for the Letter 
Number Sequencing and spatial span tasks separately, thus, we have excluded this study in this moderator analysis. The statistics for the verbal and spatial WM tasks are presented in Table 3 and Figure 3. The individuals with ASD exhibited significant impairments in both spatial and verbal WM, with a medium to large effect size for spatial WM $(d=-0.72)$ and a small to medium effect size for verbal WM $(d=-0.44)$. The results of the moderator analysis indicated a significant difference between spatial and verbal WM $(Q=13.71, p<0.001)$, which suggests that individuals with ASD exhibited more severe impairments in spatial WM compared with verbal WM.

\section{INSERT TABLE 3 HERE}

\section{INSERT FIGURE 3 HERE}

\subsubsection{Effect of the component of cognitive processing in WM}

To determine whether individuals with ASD exhibited a differential deficit for different components of cognitive processing (maintenance vs. maintenance plus manipulation), we conducted a moderator analysis. We excluded four contrasts (Crane et al., 2011; Nyden et al., 1999; Poirier et al., 2011, exp1; Williams et al., 2005a), a digit span test from Nakahachi et al. (2006) and Williams et al. (2006) and a spatial span test from Williams et al. (2005b) from the moderator analysis. This is because the authors of these studies only reported the total score of the digit span task or the spatial span task and not the individual forward and backward subtest scores. The results demonstrated that individuals with ASD did not exhibit a more 
severe impairment on the WM tasks with a maintenance plus manipulation

component compared with the tasks with only a maintenance component $(Q=0.14$, $p=0.713)$ (Table 4 and Figure 4).

\section{INSERT TABLE 4 HERE}

INSERT FIGURE 4 HERE

Effect of cognitive load analysis of $n$-back task

The $n$-back task provides another method to examine the effect of cognitive load, thus, we investigated whether the WM load (1-back vs. 2-back) affected WM impairments in individuals with ASD. The results indicated there was no significant difference between 1-back and 2-back tasks $(Q=0.029, p=0.864)$ (Table 5 and Figure 5).

\section{INSERT TABLE 5 HERE \\ INSERT FIGURE 5 HERE}

\subsubsection{Effects of age and IQ}

We conducted a meta-regression analysis with the age of the individuals with ASD as the predictor and the effect size of WM impairments as the dependent variable. The results demonstrated that the effect of age was not significant (slope estimate $b$ $=-0.0001, Z=-0.02, p=0.987)$. A similar analysis using IQ as the predictor indicated 
that the effect of IQ on WM impairment was not significant (slope estimate $B=$ $-0.007, Z=-0.85, p=0.398)$.

\section{Discussion}

The main findings of the current meta-analysis are: overall, individuals with ASD were impaired in WM; individuals with ASD diagnosed using both the ADI/ADOS and DSM/ICD criteria exhibited more severe WM impairments compared with individuals who were diagnosed using only the ADI/ADOS or only the DSM/ICD diagnostic criteria; spatial WM was more impaired than verbal WM in individuals with ASD; the component of cognitive processing and cognitive load did not affect the extent of WM impairments in individuals with ASD; and age and IQ were not associated with WM impairments in individuals with ASD.

\subsection{Overall WM impairment in ASD}

Individuals with ASD exhibited significant WM impairment, which is consistent with most previous studies (Boucher et al., 2012; Kercood et al., 2014). This finding is likely a result of the brain abnormalities found in these individuals. For example, individuals with ASD have been demonstrated to have structural brain abnormalities, such as an enlarged brain size and weight in childhood, particularly in the frontal lobes (Courchesne \& Pierce, 2005; Redcay \& Courchesne, 2005). Moreover, studies have identified brain hyperconnectivity at the whole-brain and subsystems levels across long- and short-range connections (Lynch et al., 2013; Supekar et al., 2013; 
Uddin et al., 2013). Brain hyperconnectivity may result in the isolation of the neural systems involved in high-level cognitive processes, thus, contributing to the core deficits of ASD, such as cognitive functions, social and emotional processing and communication, and speech (Courchesne \& Pierce, 2005; Courchesne et al., 2007; Lynch et al., 2013; Supekar et al., 2013; Uddin et al., 2013).

\subsection{Effect of diagnostic criteria}

The present results suggest that the diagnostic criteria used were related to WM impairments in ASD. No studies have directly investigated whether there were differences in WM performance between individuals with ASD who were diagnosed using different criteria, however, the present result is consistent with a previous proposal. Luna et al. (2007) identified WM impairments in individuals with ASD, which is in contrast to Edgin and Pennington (2005). Luna et al. (2007) suggested that the discrepancy might have occurred because they used the ADOS in addition to the ADI used by Edgin and Pennington (2005). This approach might have resulted in a more conservative diagnosis of autism, and the clinical participants were determined to be more impaired in WM. The ADI/ADOS are based on the DSM-IV; however, the studies with both the ADI/ADOS and DSM-IV/ICD diagnostic criteria indicated greater impairments compared with the studies with only the ADI/ADOS or DSM-IV/ICD. One confounding factor may be that the functional level of the participants may be different, that is, there may be more high functioning individuals with ASD with only one of the criteria and more low functioning individuals with ASD with both criteria. 
However, our results that indicated IQ was not related to WM impairments excluded this possibility. We suggest that including both criteria may result in a more conservative diagnosis of autism, which is related to more severe impairments in WM.

\subsection{Effect of WM type}

In general, individuals with ASD exhibited an impaired verbal ability and, in some cases, superior visual ability (e.g., as manifested in the Block Design task and the Children's Embedded Figures Task) (Jolliffe \& Baron-Cohen, 1997; Morgan, Maybery, \& Durkin, 2003). Studies have demonstrated that individuals with ASD tend to process stimuli visually to compensate for their language deficits (Koshino et al., 2005; Koshino et al., 2008), thus, one may propose that the visuospatial WM may be intact because their superior visuospatial ability may compensate for their central executive impairments. However, the results of the current meta-analysis indicated that visuospatial WM was more impaired than verbal WM. This finding is consistent with a recent review (Kercood et al., 2014) that suggested that individuals with ASD were impaired in WM tasks, particularly tasks that require spatial WM. It also exhibited a similar pattern as reported by Williams and colleagues (Williams, Goldstein, Carpenter, et al., 2005; Williams, Goldstein, \& Minshew, 2005), in which individuals with ASD were determined to be intact in terms of verbal WM and impaired in terms of spatial WM.

We explain the results in the following ways: First, individuals with ASD may tend 
to process low-level visual features (details); however, they may not be able to integrate features into global structures to reflect the hierarchical nature of the environmental stimuli. This is also referred to as "local bias" (Plaisted, Swettenham, \& Rees, 1999). Therefore, it is difficult for them to identify the key meaning of environmental stimuli (e.g., Hill \& Frith, 2003; Luna et al., 2002). Second, individuals with ASD may have a reduced use of structure and an enhanced retention of trivial details. The retained details may interfere with rather than enhance WM, which in turn presents as more impaired spatial WM (Williams, Goldstein, \& Minshew, 2005). Third, verbal information may provide a degree of scaffolding for memory; however, there is no analogue in spatial memory, and the brain may thus have to use more computation to achieve the same degree of accuracy (Williams, Goldstein, Carpenter, et al., 2005). As a result, visuospatial WM was, in a sense, more difficult than verbal WM. A fourth possibility is that the brain areas related to visuospatial WM were more impaired compared with the regions related to verbal WM. However, to date, there is no direct evidence to support this possibility.

In general, WM is believed to be associated with the dorsolateral prefrontal cortex and related areas. A meta-analysis (Owen, McMillan, Laird, \& Bullmore, 2005) indicated that the dorsal cingulate, medial premotor cortex, dorsolateral and ventrolateral prefrontal cortex, frontal poles, and medial and lateral posterior parietal cortex were activated during $\mathrm{N}$-back tasks. Studies have demonstrated that there were differences in the neural substrates associated with verbal and spatial WM. Verbal WM was mainly related to the left hemisphere, including the prefrontal 
regions, posterior parietal cortex, Broca's area, and premotor and supplementary motor areas, whereas spatial WM was predominantly related to the right hemisphere, including the frontal cortex, posterior parietal, and occipital regions (Gruber \& von Cramon, 2003; Smith \& Jonides, 1998).

Several functional neuroimaging studies have investigated WM in individuals with ASD. For example, Koshino et al. (2005) examined the neural mechanisms of WM using an $\mathrm{n}$-back task with letters in individuals with ASD. The results demonstrated that these individuals exhibited similar activation in the right hemisphere compared with the control group in contrast to substantially less activation in the left hemisphere in the dorsolateral prefrontal cortex and the inferior frontal gyrus. Individuals with ASD also exhibited more lateralized right activation in the prefrontal and parietal regions. Furthermore, individuals with ASD exhibited more activation compared with healthy controls in posterior regions, including the temporal and occipital regions. Luna et al. (2002) examined the neural correlates of spatial WM in autism, and the results indicated that individuals with autism demonstrated less activation in the dorsolateral prefrontal cortex and posterior cingulate cortex compared with controls. These findings suggested that the functional disconnectivity of the dorsal lateral prefrontal cortex and posterior cingulate cortex circuitry was related to WM impairments. They also demonstrated that the spatial WM deficit was not caused by basic sensorimotor or attention processes. From these studies, it may be inferred that individuals with ASD processed verbal stimuli in a nonverbal fashion, and the verbal stimuli were processed as visual 
codes. However, because of the limited number of related studies, it is unclear why individuals with ASD exhibited more severe visuospatial than verbal WM impairments compared with controls. Future studies are required to clarify this issue.

\subsection{Effect of component of cognitive processing and cognitive load on WM}

In this meta-analysis, the component of cognitive processing or cognitive load did not affect WM impairments in individuals with ASD, which is reflected by the analyses of maintenance plus manipulation vs. maintenance and a 1 vs. 2 n-back task. This finding is not consistent with the suggestion by Kercood et al. (2014), who demonstrated that individuals with ASD scored lower in WM measures with increasing task complexity. However, their study comprised a qualitative review, and the present study included a meta-analysis. The effect size demonstrated that individuals with ASD exhibited similar impairments on tasks that included the processes of maintenance plus manipulation compared with only maintenance. Individuals with ASD exhibited a larger effect size impairment in tasks with maintenance plus manipulation compared with tasks with only maintenance; however, this effect did not reach statistical significance. This finding suggested that individuals with ASD exhibited a prominent WM impairment with a low cognitive load; however, when the cognitive load increased, they did not exhibit a greater impairments. These results are also consistent with previous findings that demonstrated an impairment in WM was present at all delay periods, which suggests an inherent impairments in the processes involved in the maintenance and retrieval 
of internal representations (Luna et al., 2007). The effect of cognitive load in spatial WM tasks did not interact with group, which indicates that the WM performance was not more impaired as the load increased in the ASD group (Minshew, Luna, \& Sweeney, 1999; Ozonoff \& Strayer, 2001).

However, studies have also demonstrated that WM impairment was related to task demand. For example, Steele et al. (2007) demonstrated that individuals with ASD became impaired as the set size increased in spatial WM tasks. Studies have also suggested that as the complexity of stimuli increased, the WM performance in ASD decreased more rapidly compared with the controls. For example, individuals with ASD did not differ from controls with respect to letter span performance; however, they performed more poorly for word span and sentences (Minshew \& Goldstein, 2001). Individuals with ASD have been demonstrated to have intact memory for location, however, they were impaired in terms of complex visual spatial WM (Williams et al., 2006). Nevertheless, the number of these studies is too small to allow us to conduct a meta-analysis and determine whether different degrees of cognitive load would impact WM impairments.

\subsection{Effect of age}

WM abilities develop with age (Thomason et al., 2009), however, whether WM impairments in ASD also develops with age remains unclear. Happe et al. (2006) demonstrated that young children with ASD exhibited an impairment in spatial WM, whereas older children with ASD were not impaired. Nevertheless, most other 
studies have demonstrated that WM impairments persists in individuals with ASD. For example, Ozonoff and McEvoy (1994) conducted a three-year follow-up study on children with ASD and reported no improvement in WM performance. Luna et al. (2007) demonstrated that individuals with ASD exhibited persistent spatial WM impairments throughout development. The control group exhibited improvements in WM from adolescence to adulthood, whereas the ASD group only exhibited improvements from childhood to adolescence. The authors suggested that spatial WM comprises a core deficit that appeared in childhood. This ability develops with age for individuals with ASD, however, the development is delayed and reduced, which results in a persistent impairments in spatial WM. Furthermore, Geuts et al. (2012) demonstrated that older adults with ASD continued to exhibit WM impairments.

The present results demonstrated that WM impairments did not correlate with age, which thus also supports persistent WM impairments across age in individuals with ASD. Redcay and Courchesne (2005) suggested that individuals with ASD exhibited the greatest deviation from normal in brain size during the ages of 2-5 years, which may suggest they are most impaired during this age period. However, nearly all individuals with ASD included in this meta-analysis were older than this age range. It is suggested that although WM performance did develop in individuals with ASD, these individuals may continue to exhibit a stable impairment compared with controls. Furthermore, it should be noted that most of the studies were conducted in childhood and adolescence, whereas a limited number of studies were conducted in 
adults and even fewer in elderly individuals. Of particular interest is that Hallahan et al. (2009) found there was no significant difference in lobar brain matter volume between adults with ASD and controls. Additional studies using participants in all age periods are necessary to clarify this issue.

\subsection{Limitations}

There are several limitations in the present study. First, some studies demonstrated significant relationships between WM performance and clinical symptoms, such as restricted, repetitive symptoms and the social domain on the ADOS (Landa \& Goldberg, 2005; Lopez, Lincoln, Ozonoff, \& Lai, 2005; Sachse et al., 2013). However, other studies did not identify this relationship (Steele et al., 2007). The small number of studies that reported this relationship prevented us from examining this issue in our meta-analysis. Second, the number of studies that investigated the relationships between WM and other cognitive functions (Sachse et al., 2013) and daily functioning (Williams, Goldstein, \& Minshew, 2005) are also limited and therefore prevented us from examining these relationships in our current meta-analysis. Third, most studies included in the current meta-analysis were conducted using children and adolescents as participants, thus, the relationship between age and WM impairments in individuals with ASD over a broad age range could not be clarified. Fourth, individuals with ASD often have comorbid diagnoses, such as language impairments, learning disabilities, attention deficit and hyperactivity disorder (ADHD), and Tourette syndrome (TS). Verte et al. (2005) 
demonstrated that the ASD comorbid with TS group exhibited more impairments in spatial WM compared with the ASD group, thus, comorbidity is related to WM impairments in individuals with ASD. However, a limited number of studies have described the comorbidity status of the ASD group, and they did not present results for individuals with ASD with or without other comorbidities separately. Thus, this factor was not considered in this meta-analysis.

\subsection{Implications}

Notwithstanding these limitations, the present study has implications for interventions aimed at individuals with ASD. For example, two intervention studies (Baltruschat et al., 2011a, 2011b) have been conducted in individuals with ASD by reinforcing correct responses (providing children with one of their highly preferred items, such as video games, candy, movies, and stickers, for every correct response) during WM task performance. The results indicated an improved performance in WM tasks, such as counting span, complex span and digit span backwards, in the reinforcement session, and the effects were maintained in the later sessions when the positive reinforcement was removed (Baltruschat et al., 2011a, 2011b). McGovern and Sigman (2005) have suggested that interventions may improve cognitive abilities, as well as social interaction skills. An intervention that has an impact on cognitive abilities in young children with ASD is likely to have an influence on their social skills. Furthermore, WM has been related to restricted, repetitive symptoms and social functioning (Landa \& Goldberg, 2005; Lopez, Lincoln, Ozonoff, 
\& Lai, 2005; Sachse et al., 2013), thus, WM training may reduce these core symptoms and improve social functioning in individuals with ASD. However, additional studies are required to investigate this issue. Taken together, an intervention in WM is necessary for individuals with ASD, as suggested by Ansari (2015), and WM is a potential therapeutic target for the treatment of this clinical group.

\subsection{Conclusion}

The present meta-analysis indicated that individuals with ASD exhibited general impairments in WM. Specifically, their spatial WM was more impaired compared with verbal WM. The component of cognitive processing or cognitive load, age and IQ did not have an effect on WM impairments in these individuals. 
Conflict of interest

None. 
References (articles included in the meta-analysis are denoted with *)

Alloway, T. P., \& Gathercole, S. E. (2006). How does working memory work in the classroom? Educational Research and Review, 1, 134-139.

American Psychiatric Association. (1987). Diagnostic and Statistical Manual of Mental Disorders (3rd Edition, Revised). Washington, DC: American Psychiatric Association.

American Psychiatric Association. (1994). Diagnostic and Statistical Manual of Mental Disorders (4th ed.). Washington, DC: American Psychiatric Association.

American Psychiatric Association. (2000). American Psychiatric Association Diagnostic and statistical manual of mental disorders (4th ed., text revised). Washington, DC: American Psychiatric Association.

Ansari, S. (2015). The therapeutic potential of working memory training for treating mental disorders. Frontiers in Human Neuroscience, 9, 481. doi: 10.3389/fnhum.2015.00481

Baddeley, A. (Ed.). (1986). Working memory. Oxford: Oxford University Press.

Baltruschat, L., Hasselhorn, M., Tarbox, J., Dixon, D. R., Najdowski, A. C., Mullins, R. D., \& Gould, E. R. (2011a). Addressing working memory in children with autism through behavioral intervention. Research in Autism Spectrum Disorders, 5(1), 267-276. doi: 10.1016/j.rasd.2010.04.008

Baltruschat, L., Hasselhorn, M., Tarbox, J., Dixon, D. R., Najdowski, A. C., Mullins, R. D., \& Gould, E. R. (2011b). Further analysis of the effects of positive reinforcement on working memory in children with autism. Research in Autism Spectrum Disorders, 5(2), 855-863. doi: 10.1016/j.rasd.2010.09.015

Baron-Cohen, S., Leslie, A. M., \& Frith, U. (1985). Does the autistic child have a "theory of mind"? Cognition, 21(1), 37-46. doi: 10.1016/0010-0277(85)90022-8

Bennetto, L., Pennington, B. F., \& Rogers, S. J. (1996). Intact and impaired memory functions in autism. Child Development, 67(4), 1816-1835. doi: 10.1111/j.1467-8624.1996.tb01830.x

Bodner, K. E., Beversdorf, D. Q., Saklayen, S. S., \& Christ, S. E. (2012). Noradrenergic moderation of working memory impairments in adults with autism spectrum disorder. Journal of the International Neuropsychological Society, 18(3), 556-564. doi: 10.1017/S1355617712000070

Borenstein, M., Hedges, L. V., Higgins, J. P. T., \& Rothstein, H. R. (2009). Introduction to meta-analysis. West Sussex: John Wiley \& Sons, Ltd.

Boucher, J., Mayes, A., \& Bigham, S. (2012). Memory in autistic spectrum disorder. Psychological Bulletin, 138(3), 458-496. doi: 10.1037/a0026869 
Chan, R. C. K., Shum, D., Toulopoulou, T., \& Chen, E. Y. H. (2008). Assessment of executive functions: Review of instruments and identification of critical issues. Archives of Clinical Neuropsychology, 23, 201-216. doi: 10.1016/j.acn.2007.08.010

Courchesne, E., \& Pierce, K. (2005). Why the frontal cortex in autism might be talking only to itself: local over-connectivity but long-distance disconnection. Current Opinion in Neurobiology, 15(2), 225-230. doi: 10.1016/j.conb.2005.03.001

Courchesne, E., Pierce, K., Schumann, C. M., Redcay, E., Buckwalter, J. A., Kennedy, D. P., \& Morgan, J. (2007). Mapping early brain development in autism. Neuron, 56(2), 399-413. doi: 10.1016/j.neuron.2007.10.016

*Crane, L., Goddard, L., \& Pring, L. (2013). Autobiographical memory in adults with autism spectrum disorder: The role of depressed mood, rumination, working memory and theory of mind. Autism, 17(2), 205-219. doi: 10.1177/1362361311418690

*Cui, J., Gao, D., Chen, Y., Zou, X., \& Wang, Y. (2010). Working memory in early-school-age children with Asperger's syndrome. Journal of Autism and Developmental Disorders, 40(8), 958-967. doi: 10.1007/s10803-010-0943-9

Eack, S. M., Bahorik, A. L., McKnight, S. A. F., Hogarty, S. S., Greenwald, D. P., Newhill, C. E., . . Minshew, N. J. (2013). Commonalities in social and non-social cognitive impairments in adults with autism spectrum disorder and schizophrenia. Schizophrenia Research, 148(1), 24-28. doi: 10.1016/j.schres.2013.05.013

Edgin, J. O., \& Pennington, B. F. (2005). Spatial cognition in autism spectrum disorders: Superior, impaired, or just intact? Journal of Autism and Developmental Disorders, 35(6), 729-745. doi: 10.1007/s10803-005-0020-y

Filipek, P. A., Accardo, P. J., Baranek, G. T., Cook Jr, E. H., Dawson, G., Gordon, B., . . Levy, S. E. (1999). The screening and diagnosis of autistic spectrum disorders. Journal of autism and developmental disorders, 29(6), 439-484.

Frith, U. (1989). Autism: Explaining the enigma. Oxford: Blackwell.

*Gabig, C. S. (2008). Verbal working memory and story retelling in school-age children with autism. Language, Speech, and Hearing Services in Schools, 39(4), 498-511. doi: 10.1044/0161-1461(2008/07-0023)

*García-Villamisar, D., \& Sala, S. D. (2002). Dual-task performance in adults with autism. Cognitive Neuropsychiatry, 7(1), 63-74. doi: 10.1080/13546800143000140

Geschwind, D. H. (2009). Advances in autism. Annual Review of Medicine, 60, 367-380. doi: 10.1146/annurev.med.60.053107.121225 
*Geurts, H. M., Verté, S., Oosterlaan, J., Roeyers, H., \& Sergeant, J. A. (2004). How specific are executive functioning deficits in attention deficit hyperactivity disorder and autism? Journal of Child Psychology and Psychiatry, 45(4), 836-854. doi: 10.1111/j.1469-7610.2004.00276.x

*Geurts, H. M., \& Vissers, M. E. (2012). Elderly with autism: executive functions and memory. Journal of Autism and Developmental Disorders, 42(5), 665-675. doi: 10.1007/s10803-011-1291-0

Gilchrist, A., Green, J., Cox, A., Burton, D., Rutter, M., \& Le Couteur, A. (2001). Development and current functioning in adolescents with Asperger syndrome: A comparative study. Journal of Child Psychology and Psychiatry, 42(2), 227-240. doi: 10.1017/S0021963001006631

*Goldberg, M. C., Mostofsky, S. H., Cutting, L. E., Mahone, E. M., Astor, B. C., Denckla, M. B., \& Landa, R. J. (2005). Subtle executive impairment in children with autism and children with ADHD. Journal of Autism and Developmental Disorders, 35(3), 279-293. doi: $10.1007 /$ s10803-005-3291-4

*Gonzalez-Gadea, M. L., Baez, S., Torralva, T., Castellanos, F. X., Rattazzi, A., Bein, V., . . Ibanez, A. (2013). Cognitive variability in adults with ADHD and AS: disentangling the roles of executive functions and social cognition. Research in Developmental Disabilities, 34(2), 817-830. doi: 10.1016/j.ridd.2012.11.009

Gruber, O., \& von Cramon, D. Y. (2003). The functional neuroanatomy of human working memory revisited: Evidence from 3-T fMRI studies using classical domain-specific interference tasks. Neuroimage, 19(3), 797-809. doi: 10.1016/S1053-8119(03)00089-2

Hallahan, B., Daly, E. M., McAlonan, G., Loth, E., Toal, F., O'Brien, F., ... Murphy, D. G. M. (2009). Brain morphometry volume in autistic spectrum disorder: a magnetic resonance imaging study of adults. Psychological Medicine, 39, 337-346. doi: 10.1017/S0033291708003383

*Ham, H. S., Bartolo, A., Corley, M., Rajendran, G., Szabo, A., \& Swanson, S. (2011). Exploring the relationship between gestural recognition and imitation: Evidence of dyspraxia in autism spectrum disorders. Journal of Autism and Developmental Disorders, 41(1), 1-12. doi: 10.1007/s10803-010-1011-1

*Happé, F., Booth, R., Charlton, R., \& Hughes, C. (2006). Executive function deficits in autism spectrum disorders and attention-deficit/hyperactivity disorder: examining profiles across domains and ages. Brain and Cognition, 61(1), 25-39. doi: 10.1016/j.bandc.2006.03.004

Hill, E. L. (2004). Evaluating the theory of executive dysfunction in autism. Developmental Review, 24(2), 189-233. doi: 10.1016/j.dr.2004.01.001

Hill, E. L., \& Frith, U. (2003). Understanding autism: insights from mind and brain. Philosophical Transactions of the Royal Society B: Biological Sciences, 358(1430), 281-289. doi: 10.1098/rstb.2002.1209 
Jolliffe, T., \& Baron-Cohen, S. (1997). Are people with autism and Asperger syndrome faster than normal on the Embedded Figures Test? Journal of Child Psychology and Psychiatry, 38(5), 527-534. doi: 10.1111/j.1469-7610.1997.tb01539.x

*Joseph, R. M., McGrath, L. M., \& Tager-Flusberg, H. (2005). Executive dysfunction and its relation to language ability in verbal school-age children with autism. Developmental Neuropsychology, 27(3), 361-378. doi: 10.1207/s15326942dn2703_4

*Joseph, R. M., Steele, S. D., Meyer, E., \& Tager-Flusberg, H. (2005). Self-ordered pointing in children with autism: failure to use verbal mediation in the service of working memory? Neuropsychologia, 43(10), 1400-1411. doi: 10.1016/j.neuropsychologia.2005.01.010

Jurado, M. B., \& Rosselli, M. (2007). The elusive nature of executive functions: a review of our current understanding. Neuropsychology Review, 17(3), 213-233. doi: 10.1007/s11065-007-9040-z

Kamio, Y., \& Toichi, M. (2007). Memory illusion in high-functioning autism and Asperger's disorder. Journal of Autism and Developmental Disorders, 37(5), 867-876. doi: 10.1007/s10803-006-0214-y

Kanne, S. M., Gerber, A. J., Quirmbach, L. M., Sparrow, S. S., Cicchetti, D. V., \& Saulnier, C. A. (2011). The role of adaptive behavior in autism spectrum disorders: Implications for functional outcome. Journal of Autism and Developmental Disorders, 41(8), 1007-1018. doi: 10.1007/s10803-010-1126-4

Kercood, S., Grskovic, J. A., Banda, D., \& Begeske, J. (2014). Working memory and autism: A review of literature. Research in Autism Spectrum Disorders, 8(10), 1316-1332. doi: 10.1016/j.rasd.2014.06.011

Koshino, H., Carpenter, P. A., Minshew, N. J., Cherkassky, V. L., Keller, T. A., \& Just, M. A. (2005). Functional connectivity in an $\mathrm{fMRI}$ working memory task in high-functioning autism. Neuroimage, 24(3), 810-821. doi: 10.1016/j.neuroimage.2004.09.028

*Koshino, H., Kana, R. K., Keller, T. A., Cherkassky, V. L., Minshew, N. J., \& Just, M. A. (2008). fMRI investigation of working memory for faces in autism: visual coding and underconnectivity with frontal areas. Cerebral Cortex, 18(2), 289-300. doi: 10.1093/cercor/bhm054

*Landa, R. J., \& Goldberg, M. C. (2005). Language, social, and executive functions in high functioning autism: A continuum of performance. Journal of Autism and Developmental Disorders, 35(5), 557-573. doi: 10.1007/s10803-005-0001-1

Le Couteur, A., Rutter, M., Lord, C., Rios, P., Robertson, S., Holdgrafer, M., \& McLennan, J. (1989). Autism diagnostic interview: A standardized investigator-based instrument. Journal of Autism and Developmental Disorders, 19(3), 363-387. 
*Lopez, B. R., Lincoln, A. J., Ozonoff, S., \& Lai, Z. (2005). Examining the relationship between executive functions and restricted, repetitive symptoms of autistic disorder. Journal of Autism and Developmental Disorders, 35(4), 445-460. doi: 10.1007/s10803-005-5035-x

Lord, C., Risi, S., Lambrecht, L., Cook Jr, E. H., Leventhal, B. L., DiLavore, P. C., . . Rutter, M. (2000). The Autism Diagnostic Observation Schedule-Generic: A standard measure of social and communication deficits associated with the spectrum of autism. Journal of Autism and Developmental Disorders, 30(3), 205-223.

Lord, C., Rutter, M., Goode, S., Heemsbergen, J., Jordan, H., Mawhood, L., \& Schopler, E. (1989). Austism diagnostic observation schedule: A standardized observation of communicative and social behavior. Journal of Autism and Developmental Disorders, 19(2), 185-212. doi: 10.1007/BF02211841

Lord, C., Rutter, M., \& Le Couteur, A. (1994). Autism Diagnostic Interview-Revised: a revised version of a diagnostic interview for caregivers of individuals with possible pervasive developmental disorders. Journal of Autism and Developmental Disorders, 24(5), 659-685. doi: 10.1007/BF02172145

Luna, B., Doll, S. K., Hegedus, S. J., Minshew, N. J., \& Sweeney, J. A. (2007). Maturation of executive function in autism. Biological Psychiatry, 61(4), 474-481. doi: 10.1016/j.biopsych.2006.02.030

Luna, B., Minshew, N. J., Garver, K. E., Lazar, N. A., Thulborn, K. R., Eddy, W. F., \& Sweeney, J. A. (2002). Neocortical system abnormalities in autism An fMRI study of spatial working memory. Neurology, 59(6), 834-840. doi: 10.1212/WNL.59.6.834

Lynch, C. J., Uddin, L. Q., Supekar, K., Khouzam, A., Phillips, J., \& Menon, V. (2013). Default mode network in childhood autism: posteromedial cortex heterogeneity and relationship with social deficits. Biological psychiatry, 74(3), 212-219. doi: 10.1016/j.biopsych.2012.12.013

McGovern, C. W., \& Sigman, M. (2005). Continuity and change from early childhood to adolescence in autism. Journal of Child Psychology and Psychiatry, 46(4), 401-408. doi: 10.1111/j.1469-7610.2004.00361.x

Minshew, N. J., \& Goldstein, G. (2001). The pattern of intact and impaired memory functions in autism. Journal of Child Psychology and Psychiatry, 42(8), 1095-1101. doi: $10.1017 /$ S0021963001007867

Minshew, N. J., Luna, B., \& Sweeney, J. A. (1999). Oculomotor evidence for neocortical systems but not cerebellar dysfunction in autism. Neurology, 52(5), 917-917. doi: 10.1212/WNL.52.5.917

Morgan, B., Maybery, M., \& Durkin, K. (2003). Weak central coherence, poor joint attention, and low verbal ability: independent deficits in early autism. Developmental Psychology, 39(4), 646-656. doi: 10.1037/0012-1649.39.4.646 
Morsanyi, K., \& Holyoak, K. J. (2010). Analogical reasoning ability in autistic and typically developing children. Developmental science, 13(4), 578-587. doi: 10.1111/j.1467-7687.2009.00915.x

*Nakahachi, T., Iwase, M., Takahashi, H., Honaga, E., Sekiyama, R., Ukai, S., . . Yamashita, K. (2006). Discrepancy of performance among working memory-related tasks in autism spectrum disorders was caused by task characteristics, apart from working memory, which could interfere with task execution. Psychiatry and Clinical Neurosciences, 60(3), 312-318. doi: 10.1111/j.1440-1819.2006.01507.x

*Nydén, A., Gillberg, C., Hjelmquist, E., \& Heiman, M. (1999). Executive function/attention deficits in boys with Asperger syndrome, attention disorder and reading/writing disorder. Autism, 3(3), 213-228. doi: 10.1177/1362361399003003002

Owen, A. M., McMillan, K. M., Laird, A. R., \& Bullmore, E. (2005). N-back working memory paradigm: A meta-analysis of normative functional neuroimaging studies. Human Brain Mapping, 25(1), 46-59. doi: 10.1002/hbm.20131

Ozonoff, S., \& McEvoy, R. E. (1994). A longitudinal study of executive function and theory of mind development in autism. Development and Psychopathology, 6(3), 415-431.

Ozonoff, S., Pennington, B. F., \& Rogers, S. J. (1991). Executive function deficits in high-functioning autistic individuals: Relationship to theory of mind. Journal of Child Psychology and Psychiatry, 32(7), 1081-1105. doi: 10.1111/j.1469-7610.1991.tb00351.x

Ozonoff, S., South, M., \& Miller, J. N. (2000). DSM-IV-defined Asperger syndrome: Cognitive, behavioral and early history differentiation from high-functioning autism. Autism, 4(1), 29-46. doi: $10.1177 / 1362361300041003$

Ozonoff, S., \& Strayer, D. L. (2001). Further evidence of intact working memory in autism. Journal of Autism and Developmental Disorders, 31(3), 257-263. doi: 10.1023/A:1010794902139

Plaisted, K., Swettenham, J., \& Rees, L. (1999). Children with autism show local precedence in a divided attention task and global precedence in a selective attention task. Journal of Child Psychology and Psychiatry, 40(5), 733-742.

*Poirier, M., Martin, J. S., Gaigg, S. B., \& Bowler, D. M. (2011). Short-term memory in autism spectrum disorder. Journal of Abnormal Psychology, 120(1), 247-252. doi: 10.1037/a0022298

Rajendran, G., \& Mitchell, P. (2007). Cognitive theories of autism. Developmental Review, 27(2), 224-260. doi: 10.1016/j.dr.2007.02.001

Redcay, E., \& Courchesne, E. (2005). When is the brain enlarged in autism? A meta-analysis of all brain size reports. Biological Psychiatry, 58(1), 1-9. doi: 10.1016/j.biopsych.2005.03.026

Redick, T. S., \& Lindsey, D. R. B. (2013). Complex span and n-back measures of working memory: A meta-analysis. Psychonomic Bulletin \& Review, 20(6), 1102-1113. doi: 
$10.3758 /$ s13423-013-0453-9

Rinehart, N. J., Bradshaw, J. L., Brereton, A. V., \& Tonge, B. J. (2002). Lateralization in individuals with high-functioning autism and Asperger's disorder: a frontostriatal model. Journal of Autism and Developmental Disorders, 32(4), 321-332. doi: 10.1023/A:1016387020095

Rinehart, N. J., Bradshaw, J. L., Moss, S. A., Brereton, A. V., \& Tonge, B. J. (2001). A deficit in shifting attention present in high-functioning autism but not Asperger's disorder. Autism, 5(1), 67-80. doi: $10.1177 / 1362361301005001007$

Rosenthal, R. (1979). The file drawer problem and tolerance for null results. Psychological Bulletin, 86(3), 638-641.

*Russell, J., Jarrold, C., \& Henry, L. (1996). Working memory in children with autism and with moderate learning difficulties. Journal of Child Psychology and Psychiatry, 37(6), 673-686. doi: 10.1111/j.1469-7610.1996.tb01459.x

*Sachse, M., Schlitt, S., Hainz, D., Ciaramidaro, A., Schirman, S., Walter, H., . . Freitag, C. M. (2013). Executive and visuo-motor function in adolescents and adults with autism spectrum disorder. Journal of Autism and Developmental Disorders, 43(5), 1222-1235. doi: 10.1007/s10803-012-1668-8

Smith, E. E., \& Jonides, J. (1998). Neuroimaging analyses of human working memory. Proceedings of the National Academy of Sciences, 95(20), 12061-12068. doi: 10.1073/pnas.95.20.12061

*Steele, S. D., Minshew, N. J., Luna, B., \& Sweeney, J. A. (2007). Spatial working memory deficits in autism. Journal of Autism and Developmental Disorders, 37(4), 605-612. doi: $10.1007 / \mathrm{s} 10803-006-0202-2$

Supekar, K., Uddin, L. Q., Khouzam, A., Phillips, J., Gaillard, W. D., Kenworthy, L. E., . . Menon, V. (2013). Brain hyperconnectivity in children with autism and its links to social deficits. Cell reports, 5(3), 738-747. doi: 10.1016/j.celrep.2013.10.001

Szatmari, P., Tuff, L., Finlayson, M. A. J., \& Bartolucci, G. (1990). Asperger's syndrome and autism: Neurocognitive aspects. Journal of the American Academy of Child \& Adolescent Psychiatry, 29(1), 130-136. doi: 10.1097/00004583-199001000-00021

Thomason, M. E., Race, E., Burrows, B., Whitfield-Gabrieli, S., Glover, G. H., \& Gabrieli, J. D. E. (2009). Development of spatial and verbal working memory capacity in the human brain. Journal of Cognitive Neuroscience, 21(2), 316-332. doi: 10.1162/jocn.2008.21028

Uddin, L. Q., Supekar, K., Lynch, C. J., Khouzam, A., Phillips, J., Feinstein, C., . . Menon, V. (2013). Salience network-based classification and prediction of symptom severity in children with autism. JAMA psychiatry, 70(8), 869-879. doi: 10.1001/jamapsychiatry.2013.104 
*Verté, S., Geurts, H. M., Roeyers, H., Oosterlaan, J., \& Sergeant, J. A. (2006). The relationship of working memory, inhibition, and response variability in child psychopathology. Journal of Neuroscience Methods, 151(1), 5-14. doi: 10.1016/j.jneumeth.2005.08.023

*Verte, S., Geurts, H. M., Roeyers, H., Oosterlaan, J., \& Sergeant, J. A. (2005). Executive functioning in children with autism and Tourette syndrome. Development and Psychopathology, 17(2), 415-445. doi: 10.10170S0954579405050200

*Williams, D. L., Goldstein, G., Carpenter, P. A., \& Minshew, N. J. (2005). Verbal and spatial working memory in autism. Journal of Autism and Developmental Disorders, 35(6), 747-756. doi: 10.1007/s10803-005-0021-x

*Williams, D. L., Goldstein, G., \& Minshew, N. J. (2005). Impaired memory for faces and social scenes in autism: clinical implications of memory dysfunction. Archives of Clinical Neuropsychology, 20(1), 1-15. doi: 10.1016/j.acn.2002.08.001

*Williams, D. L., Goldstein, G., \& Minshew, N. J. (2006). The profile of memory function in children with autism. Neuropsychology, 20(1), 21-29. doi: 10.1037/0894-4105.20.1.21

World Health Organization. (1992). The ICD-10 classification of mental and behavioural disorders. Geneva: World Health Organization.

*Yi, L., Fan, Y., Joseph, L., Huang, D., Wang, X. L., Li, J., \& Zou, X. (2014). Event-based prospective memory in children with autism spectrum disorder: The role of executive function. Research in Autism Spectrum Disorders, 8(6), 654-660. doi: 10.1016/j.rasd.2014.03.005

*Zinke, K., Fries, E., Altgassen, M., Kirschbaum, C., Dettenborn, L., \& Kliegel, M. (2010). Visuospatial short-term memory explains deficits in tower task planning in high-functioning children with autism spectrum disorder. Child Neuropsychology, 16(3), 229-241. doi:

10.1080/09297040903559648 
Table 1 Descriptions of studies included in the meta-analysis

\begin{tabular}{|c|c|c|c|c|c|c|c|c|c|c|c|c|}
\hline \multirow[t]{2}{*}{$\begin{array}{l}\text { Study } \\
\text { Name }\end{array}$} & \multicolumn{4}{|c|}{ Patient Group } & \multicolumn{3}{|c|}{ Control Group } & \multirow[t]{2}{*}{$\begin{array}{r}\text { WM } \\
\text { Measurement }\end{array}$} & \multirow[t]{2}{*}{$\begin{array}{l}\text { WM } \\
\text { Type }\end{array}$} & \multirow[t]{2}{*}{$\begin{array}{l}\text { Cognitive } \\
\text { Process }\end{array}$} & \multirow[t]{2}{*}{ Basic Findings } & \multirow[t]{2}{*}{ Notes } \\
\hline & $\mathbf{N}$ & $\begin{array}{l}\text { Diagnostic } \\
\text { Criteria }\end{array}$ & $\begin{array}{l}\text { Mean } \\
\text { Age } \\
\text { (SD) }\end{array}$ & IQ & $\mathbf{N}$ & $\begin{array}{l}\text { Mean } \\
\text { Age } \\
\text { (SD) }\end{array}$ & IQ & & & & & \\
\hline $\begin{array}{l}\text { Crane et } \\
\text { al., } 2011\end{array}$ & 28 & DSM-IV/ICD-10 & $\begin{array}{l}41.57 \\
(16.49)\end{array}$ & $\begin{array}{l}117.18 \\
(13.47)\end{array}$ & 28 & $\begin{array}{l}40.53 \\
(17.20)\end{array}$ & $\begin{array}{l}115.11 \\
(11.67)\end{array}$ & $\begin{array}{l}\text { Letter-Number } \\
\text { Sequencing } \\
\text { Spatial Span } \\
\text { task }^{\#}\end{array}$ & & & $\begin{array}{l}\text { The ASD group exhibited a } \\
\text { reduction in working } \\
\text { memory abilities. }\end{array}$ & $\begin{array}{l}\text { Typical adults were matched } \\
\text { for age, gender and IQ with } \\
\text { the ASD group. }\end{array}$ \\
\hline $\begin{array}{l}\text { Cui et al., } \\
2010\end{array}$ & 12 & DSM-IV & $\begin{array}{l}7.46 \\
(0.84)\end{array}$ & $\begin{array}{l}100.03 \\
(17.13)\end{array}$ & 29 & $\begin{array}{l}7.37 \\
(0.48)\end{array}$ & $\begin{array}{l}108.31 \\
(14.08)\end{array}$ & $\begin{array}{l}\text { Digit Recall task, } \\
\text { Word List Recall, } \\
\text { Backward Digit } \\
\text { Recall, } \\
\text { Counting Recall, } \\
\text { Block Recall, } \\
\text { Variant-Visual- } \\
\text { Pattern Test, } \\
\text { Digit N-back } \\
\text { task, } \\
\text { Figure N-Back } \\
\text { task, } \\
\text { Location N-Back } \\
\text { task }\end{array}$ & $\begin{array}{l}\text { verbal } \\
\text { verbal } \\
\text { verbal } \\
\text { verbal } \\
\text { spatial } \\
\text { spatial } \\
\text { verbal } \\
\text { spatial } \\
\text { spatial }\end{array}$ & $\begin{array}{l}\text { maintenance } \\
\text { maintenance } \\
\text { manipulation } \\
\text { manipulation } \\
\text { maintenance } \\
\text { maintenance } \\
\text { manipulation } \\
\text { manipulation } \\
\text { manipulation }\end{array}$ & $\begin{array}{l}\text { The ASD children had an } \\
\text { advantage in phonological } \\
\text { loop storing and a } \\
\text { disadvantage in visuospatial } \\
\text { sketchpad storing. }\end{array}$ & $\begin{array}{l}\text { Healthy children were } \\
\text { matched for age and IQ with } \\
\text { children with ASD. }\end{array}$ \\
\hline $\begin{array}{l}\text { Gabig, } \\
2008\end{array}$ & 15 & $\begin{array}{l}\text { at least one of } \\
\text { ADI-R, ADOS, }\end{array}$ & $\begin{array}{l}6.5 \\
(0.70)\end{array}$ & None & 10 & $\begin{array}{l}6.70 \\
(0.89)\end{array}$ & None & $\begin{array}{l}\text { Nonword } \\
\text { Repetition, }\end{array}$ & verbal & maintenance & $\begin{array}{l}\text { A profile of verbal working } \\
\text { memory deficits was }\end{array}$ & $\begin{array}{l}\text { Typically developing children } \\
\text { were chronologically }\end{array}$ \\
\hline
\end{tabular}




\begin{tabular}{|c|c|c|c|c|c|c|c|c|c|c|c|c|}
\hline & & DSM-IV & & & & & & $\begin{array}{l}\text { Digits Span, } \\
\text { Sentence } \\
\text { Imitation }\end{array}$ & $\begin{array}{l}\text { verbal } \\
\text { verbal }\end{array}$ & $\begin{array}{l}\text { maintenance } \\
\text { maintenance }\end{array}$ & $\begin{array}{l}\text { identified in children with } \\
\text { autism, with poorer } \\
\text { performance in more } \\
\text { complex verbal memory } \\
\text { tasks. }\end{array}$ & $\begin{array}{l}\text { age-matched with children } \\
\text { with autism. }\end{array}$ \\
\hline $\begin{array}{l}\text { Garcia- } \\
\text { Villamisar } \\
\text { et al., } \\
2002\end{array}$ & 16 & DSM-IV & $\begin{array}{l}23.5 \\
(4.31)\end{array}$ & None & 16 & $\begin{array}{l}21.19 \\
(2.51)\end{array}$ & None & $\begin{array}{l}\text { Forward Digit } \\
\text { Recall task }\end{array}$ & verbal & maintenance & $\begin{array}{l}\text { The difference in the mean } \\
\text { Digit Span for the autistic } \\
\text { and control groups was not } \\
\text { statistically significant. }\end{array}$ & $\begin{array}{l}\text { The two groups did not differ } \\
\text { in chronological age or } \\
\text { educational level. }\end{array}$ \\
\hline $\begin{array}{l}\text { Geurts et } \\
\text { al., } 2004\end{array}$ & 41 & ADI-R & $\begin{array}{l}9.4 \\
(1.8)\end{array}$ & $\begin{array}{l}98.3 \\
(18.4)\end{array}$ & 41 & $\begin{array}{l}9.1 \\
(1.7)\end{array}$ & $\begin{array}{l}111.5 \\
(18.0)\end{array}$ & $\begin{array}{l}\text { Self-Ordered } \\
\text { Pointing task, } \\
\text { Benton Visual } \\
\text { Retention test, } \\
\text { Corsi Block } \\
\text { Tapping test }\end{array}$ & $\begin{array}{l}\text { spatial } \\
\text { spatial } \\
\text { spatial }\end{array}$ & $\begin{array}{l}\text { manipulation } \\
\text { maintenance } \\
\text { maintenance }\end{array}$ & $\begin{array}{l}\text { Children with ASD } \\
\text { demonstrated no deficits in } \\
\text { working memory, whereas } \\
\text { they exhibited poorer } \\
\text { short-term memory } \\
\text { compared with the normal } \\
\text { control group. }\end{array}$ & $\begin{array}{l}\text { Study investigated } \\
\text { age-matched child groups: } \\
\text { HFA and normal controls. }\end{array}$ \\
\hline $\begin{array}{l}\text { Geurts et } \\
\text { al., } 2012\end{array}$ & 23 & DSM-IV, SRS & $\begin{array}{l}63.6 \\
(7.5)\end{array}$ & $\begin{array}{l}109.5 \\
(10.3)\end{array}$ & 23 & $\begin{array}{l}63.7 \\
(8.1)\end{array}$ & $\begin{array}{l}109.8 \\
(7.9)\end{array}$ & $\begin{array}{l}\text { Forward Spatial } \\
\text { Span task }\end{array}$ & spatial & maintenance & $\begin{array}{l}\text { Elderly individuals with } \\
\text { autism exhibited visual } \\
\text { working memory problems } \\
\text { compared with the control } \\
\text { group. }\end{array}$ & $\begin{array}{l}\text { The control group was } \\
\text { matched for age and gender } \\
\text { with the autism group. }\end{array}$ \\
\hline $\begin{array}{l}\text { Goldberg } \\
\text { et al., } 2005\end{array}$ & 17 & $\begin{array}{l}\text { ADI-R, } \\
\text { ADOS/ADOS-G }\end{array}$ & $\begin{array}{l}10.3 \\
(1.8)\end{array}$ & $\begin{array}{l}96.5 \\
(15.9)\end{array}$ & 32 & $\begin{array}{l}10.4 \\
(1.5)\end{array}$ & $\begin{array}{l}112.6 \\
(12.1)\end{array}$ & $\begin{array}{l}\text { CANTAB Spatial } \\
\text { Working } \\
\text { Memory task }\end{array}$ & spatial & manipulation & $\begin{array}{l}\text { Spatial working memory is } \\
\text { severely impaired in ASD } \\
\text { individuals compared with } \\
\text { healthy controls. }\end{array}$ & $\begin{array}{l}\text { The healthy controls were } \\
\text { chronological age-matched } \\
\text { with ASD individuals. }\end{array}$ \\
\hline Gonzalez- & 23 & DSM-IV & 33.0 & None & 21 & 38.2 & None & Backward Digit & verbal & manipulation & The ASD group was not & The typically developing \\
\hline
\end{tabular}




\begin{tabular}{|c|c|c|c|c|c|c|c|c|c|c|c|c|}
\hline $\begin{array}{l}\text { Gadea et } \\
\text { al., } 2013\end{array}$ & & & (9.8) & & & (14.4) & & $\begin{array}{l}\text { Span, } \\
\text { Letters and } \\
\text { Numbers }\end{array}$ & verbal & manipulation & $\begin{array}{l}\text { significantly difference from } \\
\text { the typically developing } \\
\text { control group in working } \\
\text { memory. }\end{array}$ & $\begin{array}{l}\text { controls were matched with } \\
\text { the ASD group for sex, age, } \\
\text { handedness, years of } \\
\text { education and intellectual } \\
\text { level. }\end{array}$ \\
\hline $\begin{array}{l}\text { Ham et al., } \\
2011\end{array}$ & 19 & DSM-IV, ADOS & $\begin{array}{l}12.1 \\
(2.4)\end{array}$ & $\begin{array}{l}106.0 \\
(21.0)\end{array}$ & 23 & $\begin{array}{l}12.0 \\
(2.1)\end{array}$ & $\begin{array}{l}111.4 \\
(16.5)\end{array}$ & $\begin{array}{l}\text { Digit Recall task, } \\
\text { Word List } \\
\text { Matching, } \\
\text { Listening Recall } \\
\text { task }\end{array}$ & $\begin{array}{l}\text { verbal } \\
\text { verbal } \\
\text { verbal }\end{array}$ & $\begin{array}{l}\text { maintenance } \\
\text { maintenance } \\
\text { manipulation }\end{array}$ & $\begin{array}{l}\text { The participants with ASD } \\
\text { did not differ from the } \\
\text { typically developing control } \\
\text { group in the test for Digit } \\
\text { Recall; however, they } \\
\text { performed significantly } \\
\text { more poorly on the tests of } \\
\text { Word List Matching and } \\
\text { Listening Recall. }\end{array}$ & $\begin{array}{l}\text { The typically developing } \\
\text { children were matched to the } \\
\text { ASD group for age, gender } \\
\text { and Full Scale Intelligence. }\end{array}$ \\
\hline $\begin{array}{l}\text { Happe et } \\
\text { al., } 2006\end{array}$ & 32 & DSM-IV & $\begin{array}{l}10.9 \\
(2.4)\end{array}$ & $\begin{array}{l}99.7 \\
(18.7)\end{array}$ & 32 & $\begin{array}{l}11.2 \\
(2.0)\end{array}$ & $\begin{array}{l}106.8 \\
(13.4)\end{array}$ & $\begin{array}{l}\text { CANTAB Spatial } \\
\text { Working } \\
\text { Memory }\end{array}$ & spatial & manipulation & $\begin{array}{l}\text { The ASD children performed } \\
\text { poorly in spatial working } \\
\text { memory compared with the } \\
\text { typically developing } \\
\text { children. }\end{array}$ & $\begin{array}{l}\text { The typically developing } \\
\text { children were age- and } \\
\text { IQ-matched with ASD. }\end{array}$ \\
\hline $\begin{array}{l}\text { Joseph et } \\
\text { al., 2005a }\end{array}$ & 24 & $\begin{array}{l}\text { ADI-R, ADOS, } \\
\text { DSM-IV }\end{array}$ & $8.9(2.3)$ & $96(18)$ & 24 & $8.9(2.2)$ & $92(13)$ & $\begin{array}{l}\text { Verbal Span } \\
\text { test, } \\
\text { Self-Ordered } \\
\text { Pointing test, } \\
\text { Non-Verbal } \\
\text { Self-Ordered } \\
\text { Pointing test }\end{array}$ & $\begin{array}{l}\text { verbal } \\
\text { spatial } \\
\text { spatial }\end{array}$ & $\begin{array}{l}\text { maintenance } \\
\text { manipulation } \\
\text { manipulation }\end{array}$ & $\begin{array}{l}\text { The autism group } \\
\text { performed significantly less } \\
\text { well in the former but not } \\
\text { the latter self-ordered } \\
\text { pointing test. }\end{array}$ & $\begin{array}{l}\text { The comparison group was } \\
\text { matched to the autism group } \\
\text { in age and verbal and } \\
\text { non-verbal IQ. }\end{array}$ \\
\hline
\end{tabular}




\begin{tabular}{|c|c|c|c|c|c|c|c|c|c|c|c|c|}
\hline $\begin{array}{l}\text { Joseph et } \\
\text { al., 2005b }\end{array}$ & 37 & $\begin{array}{l}\text { ADI-R, ADOS, } \\
\text { DSM-IV }\end{array}$ & $7.9(1.8)$ & & 31 & $8.3(2.1)$ & & $\begin{array}{l}\text { Forward Word } \\
\text { Span task, } \\
\text { Backward Word } \\
\text { Span task, } \\
\text { Forward Block } \\
\text { Span task, } \\
\text { Backward Block } \\
\text { Span task }\end{array}$ & $\begin{array}{l}\text { verbal } \\
\text { verbal } \\
\text { spatial } \\
\text { spatial }\end{array}$ & $\begin{array}{l}\text { maintenance } \\
\text { manipulation } \\
\text { maintenance } \\
\text { manipulation }\end{array}$ & $\begin{array}{l}\text { The children with autism } \\
\text { performed significantly less } \\
\text { well on Block Span } \\
\text { Backward. }\end{array}$ & $\begin{array}{l}\text { The non-autistic comparison } \\
\text { participants were matched for } \\
\text { age and verbal and nonverbal } \\
\text { IQ but not for language ability. }\end{array}$ \\
\hline $\begin{array}{l}\text { Koshino et } \\
\text { al., } 2008\end{array}$ & 11 & ADI, ADOS & $\begin{array}{l}24.5 \\
(10.2)\end{array}$ & $\begin{array}{l}104.5 \\
(13.1)\end{array}$ & 11 & $\begin{array}{l}28.7 \\
(10.9)\end{array}$ & $\begin{array}{l}108.6 \\
(9.1)\end{array}$ & $\begin{array}{l}\text { Face N-Back } \\
\text { task }\end{array}$ & spatial & manipulation & $\begin{array}{l}\text { The autism and control } \\
\text { groups exhibited similar } \\
\text { N-Back working memory } \\
\text { task performance. }\end{array}$ & $\begin{array}{l}\text { The control group was } \\
\text { matched for age, Full Scale IQ, } \\
\text { gender, race, and } \\
\text { socioeconomic status. }\end{array}$ \\
\hline $\begin{array}{l}\text { Landa et } \\
\text { al., } 2005\end{array}$ & 19 & $\begin{array}{l}\text { ADI-R, } \\
\text { ADOS/ADOS-G }\end{array}$ & $\begin{array}{l}11.01 \\
(2.89)\end{array}$ & $\begin{array}{l}109.7 \\
(15.80)\end{array}$ & 19 & $\begin{array}{l}11.00 \\
(2.85)\end{array}$ & $\begin{array}{l}113.4 \\
(14.34)\end{array}$ & $\begin{array}{l}\text { CANTAB Spatial } \\
\text { Working } \\
\text { Memory }\end{array}$ & spatial & manipulation & $\begin{array}{l}\text { Compared with the controls, } \\
\text { the participants with ASD } \\
\text { more frequently made } \\
\text { between-search errors and } \\
\text { poorly used search } \\
\text { strategies. }\end{array}$ & $\begin{array}{l}\text { The controls were individually } \\
\text { matched to the participants } \\
\text { with ASD based on } \\
\text { chronological age, gender, and } \\
\text { full scale IQ. }\end{array}$ \\
\hline $\begin{array}{l}\text { Lopez et } \\
\text { al., } 2005\end{array}$ & 17 & ADI-R, ADOS-G & $\begin{array}{l}29.1 \\
(8.0)\end{array}$ & $\begin{array}{l}77 \\
(15)\end{array}$ & 17 & $\begin{array}{l}29.4 \\
(11.4)\end{array}$ & $\begin{array}{l}89 \\
(13)\end{array}$ & $\begin{array}{l}\text { Letter-Number } \\
\text { Sequencing }\end{array}$ & verbal & manipulation & $\begin{array}{l}\text { The two groups did not } \\
\text { differ in a measure of } \\
\text { working memory. }\end{array}$ & $\begin{array}{l}\text { The control group was } \\
\text { matched for age, gender and } \\
\text { Performance IQ with the } \\
\text { autism group. }\end{array}$ \\
\hline $\begin{array}{l}\text { Nakahachi } \\
\text { et al., } 2006\end{array}$ & 16 & DSM-IV & 28 & 101 & 28 & 28.3 & 103 & $\begin{array}{l}\text { WM ratio in } \\
\text { Advanced Trail } \\
\text { Making test, } \\
\text { Digit Span test", }\end{array}$ & verbal & maintenance & $\begin{array}{l}\text { The ASD subjects have intact } \\
\text { working memory. }\end{array}$ & $\begin{array}{l}\text { The control subjects were IQ-, } \\
\text { age- and sex-matched with } \\
\text { ASD subjects. }\end{array}$ \\
\hline
\end{tabular}




\begin{tabular}{|c|c|c|c|c|c|c|c|c|c|c|c|c|}
\hline & & & & & & & & $\begin{array}{l}\text { Digit Symbol } \\
\text { task }\end{array}$ & verbal & maintenance & & \\
\hline $\begin{array}{l}\text { Nydén et } \\
\text { al., } 1999\end{array}$ & 10 & $\begin{array}{l}\text { DSM-IV, Gillberg } \\
\text { and Gillberg } \\
\text { (1989) criteria }\end{array}$ & $\begin{array}{l}10.1 \\
(0.9)\end{array}$ & $\begin{array}{l}100.7 \\
(16.3)\end{array}$ & 10 & $\begin{array}{l}10.0 \\
(0.9)\end{array}$ & None & $\begin{array}{l}\text { Digit Span task } \\
\text { from WISC-III" }\end{array}$ & verbal & & $\begin{array}{l}\text { The ASD group exhibited } \\
\text { deficits in working memory } \\
\text { compared with the } \\
\text { population norm. }\end{array}$ & $\begin{array}{l}\text { The normal children were } \\
\text { matched for age with children } \\
\text { with ASD. }\end{array}$ \\
\hline $\begin{array}{l}\text { Poirier et } \\
\text { al., } \\
\text { 2011exp1 }\end{array}$ & 16 & $\begin{array}{l}\text { DSM-IV, part of } \\
\text { participants } \\
\text { with ADOS }\end{array}$ & $\begin{array}{l}31.6 \\
(11.4)\end{array}$ & $\begin{array}{l}100.3 \\
(16.2)\end{array}$ & 16 & $\begin{array}{l}34.8 \\
(10.8)\end{array}$ & $\begin{array}{l}102.4 \\
(11.9)\end{array}$ & Digit Recall task ${ }^{*}$ & verbal & & $\begin{array}{l}\text { The ASD group exhibited } \\
\text { poorer working memory } \\
\text { compared with the }\end{array}$ & $\begin{array}{l}\text { The typical individuals were } \\
\text { matched for age and IQ with } \\
\text { individuals with ASD. }\end{array}$ \\
\hline $\begin{array}{l}\text { Poirier et } \\
\text { al., } \\
\text { 2011exp2 }\end{array}$ & 22 & $\begin{array}{l}\text { DSM-IV, part of } \\
\text { participants } \\
\text { with ADOS }\end{array}$ & $\begin{array}{l}37.6 \\
(13.3)\end{array}$ & $\begin{array}{l}106.9 \\
(18.8)\end{array}$ & 22 & $\begin{array}{l}37.3 \\
(11.3)\end{array}$ & $\begin{array}{l}110.7 \\
(12.6)\end{array}$ & $\begin{array}{l}\text { Immediate } \\
\text { Serial Recall } \\
\text { task }\end{array}$ & verbal & maintenance & $\begin{array}{l}\text { comparison participants in } \\
\text { all three experiments. }\end{array}$ & \\
\hline $\begin{array}{l}\text { Poirier et } \\
\text { al., } \\
\text { 2011exp3 }\end{array}$ & 18 & $\begin{array}{l}\text { DSM-IV, part of } \\
\text { participants } \\
\text { with ADOS }\end{array}$ & $\begin{array}{l}40.3 \\
(13.6)\end{array}$ & $\begin{array}{l}107.8 \\
(12.9)\end{array}$ & 18 & $\begin{array}{l}41.0 \\
(11.1)\end{array}$ & $\begin{array}{l}107.2 \\
(14.4)\end{array}$ & $\begin{array}{l}\text { Order } \\
\text { Recognition test }\end{array}$ & verbal & maintenance & & \\
\hline $\begin{array}{l}\text { Russell et } \\
\text { al., } \\
\text { 1996exp1 }\end{array}$ & 33 & DSM III-R & $\begin{array}{l}12.38 \\
(2.95)\end{array}$ & none & 33 & $\begin{array}{l}6.28 \\
(1.19)\end{array}$ & none & $\begin{array}{l}\text { Word Recall } \\
\text { task, } \\
\text { Non-Verbal } \\
\text { Word Recall task }\end{array}$ & $\begin{array}{l}\text { verbal } \\
\text { spatial }\end{array}$ & $\begin{array}{l}\text { Maintenance } \\
\text { maintenance }\end{array}$ & $\begin{array}{l}\text { Children with autism were } \\
\text { at least as likely as the } \\
\text { normal group to employ } \\
\text { articulatory rehearsal. }\end{array}$ & $\begin{array}{l}\text { The normal group was } \\
\text { chronologically } \\
\text { age-appropriate. }\end{array}$ \\
\hline $\begin{array}{l}\text { Russell et } \\
\text { al., } \\
\text { 1996exp2 }\end{array}$ & 22 & DSM III-R & $\begin{array}{l}12.47 \\
(2.82)\end{array}$ & none & 22 & $\begin{array}{l}6.85 \\
(0.5)\end{array}$ & none & $\begin{array}{l}\text { Counting task, } \\
\text { Odd-Man-Out } \\
\text { task, } \\
\text { Sums task }\end{array}$ & $\begin{array}{l}\text { spatial } \\
\text { spatial } \\
\text { verbal }\end{array}$ & $\begin{array}{l}\text { Manipulation } \\
\text { manipulation } \\
\text { manipulation }\end{array}$ & $\begin{array}{l}\text { The working memory } \\
\text { performance of the children } \\
\text { with autism was inferior to } \\
\text { the normally developing } \\
\text { group. }\end{array}$ & $\begin{array}{l}\text { Normally developing children } \\
\text { were individually matched for } \\
\text { verbal mental age with } \\
\text { children with autism. }\end{array}$ \\
\hline
\end{tabular}




\begin{tabular}{|c|c|c|c|c|c|c|c|c|c|c|c|c|}
\hline $\begin{array}{l}\text { Sachse et } \\
\text { al., } 2013\end{array}$ & 30 & $\begin{array}{l}\text { DSM-IV-TR, } \\
\text { ADOS, ADI-R }\end{array}$ & $\begin{array}{l}19.2 \\
(5.1)\end{array}$ & $\begin{array}{l}105.3 \\
(12.3)\end{array}$ & 28 & $\begin{array}{l}19.9 \\
(3.6)\end{array}$ & $\begin{array}{l}109.3 \\
(11.5)\end{array}$ & $\begin{array}{l}\text { CANTAB Spatial } \\
\text { Working } \\
\text { Memory task }\end{array}$ & spatial & Manipulation & $\begin{array}{l}\text { ASD individuals exhibited } \\
\text { impaired spatial working } \\
\text { memory. }\end{array}$ & $\begin{array}{l}\text { The comparison group was } \\
\text { matched to the ASD group in } \\
\text { age, gender and non-verbal } \\
\text { IQ. }\end{array}$ \\
\hline $\begin{array}{l}\text { Steele et } \\
\text { al., } 2007\end{array}$ & 29 & $\begin{array}{l}\text { ADI-R, ADOS, } \\
\text { DSM-IV }\end{array}$ & $\begin{array}{l}14.83 \\
(5.47)\end{array}$ & $\begin{array}{l}107.76 \\
(10.99)\end{array}$ & 29 & $\begin{array}{l}16.93 \\
(5.40)\end{array}$ & $\begin{array}{l}110.79 \\
(9.91)\end{array}$ & $\begin{array}{l}\text { CANTAB Spatial } \\
\text { Working } \\
\text { Memory task }\end{array}$ & spatial & Manipulation & $\begin{array}{l}\text { Individuals with autism } \\
\text { exhibited reduced spatial } \\
\text { working memory abilities. }\end{array}$ & $\begin{array}{l}\text { Typically developing } \\
\text { individuals were matched in } \\
\text { Verbal IQ, Performance IQ, } \\
\text { age and the socioeconomic } \\
\text { status of their parents with } \\
\text { individuals with ASD. }\end{array}$ \\
\hline $\begin{array}{l}\text { Verte et } \\
\text { al., } 2005\end{array}$ & 61 & DSM-IV, ADI-R & $\begin{array}{l}9.1 \\
(1.9)\end{array}$ & $\begin{array}{l}99.2 \\
(17.1)\end{array}$ & 47 & $\begin{array}{l}9.4 \\
(1.6)\end{array}$ & $\begin{array}{l}112.1 \\
(9.7)\end{array}$ & $\begin{array}{l}\text { Self-Ordered } \\
\text { Pointing task, } \\
\text { Benton Visual } \\
\text { Retention Test, } \\
\text { Corsi Block task }\end{array}$ & $\begin{array}{l}\text { spatial } \\
\text { spatial } \\
\text { spatial }\end{array}$ & $\begin{array}{l}\text { manipulation } \\
\text { maintenance } \\
\text { maintenance }\end{array}$ & $\begin{array}{l}\text { The ASD group exhibited a } \\
\text { significantly poorer } \\
\text { performance in a spatial } \\
\text { working memory task } \\
\text { compared with the control } \\
\text { group. }\end{array}$ & $\begin{array}{l}\text { The normal control group was } \\
\text { matched for age with the ASD } \\
\text { group. }\end{array}$ \\
\hline $\begin{array}{l}\text { Verte et } \\
\text { al., } 2006\end{array}$ & 66 & DSM-IV, ADI-R & $\begin{array}{l}8.7 \\
(2.0)\end{array}$ & $\begin{array}{l}101.5 \\
(18.2)\end{array}$ & 82 & $\begin{array}{l}9.2 \\
(1.7)\end{array}$ & $\begin{array}{l}112.2 \\
(16.0)\end{array}$ & $\begin{array}{l}\text { Self-Ordered } \\
\text { Pointing task }\end{array}$ & spatial & manipulation & $\begin{array}{l}\text { More symptoms of autism } \\
\text { are related to a poorer } \\
\text { working memory process. }\end{array}$ & $\begin{array}{l}\text { The normally developing } \\
\text { children in the control group } \\
\text { were matched for age with } \\
\text { the ASD group. }\end{array}$ \\
\hline $\begin{array}{l}\text { Williams et } \\
\text { al., 2005a }\end{array}$ & 29 & $\begin{array}{l}\text { ADOS, } \\
\text { ADI/ADI-R, } \\
\text { DSM-IV }\end{array}$ & $\begin{array}{l}28.72 \\
(10.44)\end{array}$ & $\begin{array}{l}105.86 \\
(14.19)\end{array}$ & 34 & $\begin{array}{l}26.53 \\
(10.22)\end{array}$ & $\begin{array}{l}109.65 \\
(11.39)\end{array}$ & $\begin{array}{l}\text { Letter-Number } \\
\text { Sequencing, } \\
\text { Spatial Span }\end{array}$ & $\begin{array}{l}\text { verbal } \\
\text { spatial }\end{array}$ & manipulation & $\begin{array}{l}\text { The individuals with autism } \\
\text { performed as well as the } \\
\text { controls on verbal working } \\
\text { memory; however, they had } \\
\text { impaired spatial working } \\
\text { memory. }\end{array}$ & $\begin{array}{l}\text { The two groups did not } \\
\text { significantly differ with } \\
\text { respect to age, Verbal and Full } \\
\text { Scale IQ score, gender, race or } \\
\text { socioeconomic status. }\end{array}$ \\
\hline
\end{tabular}




\begin{tabular}{|c|c|c|c|c|c|c|c|c|c|c|c|c|}
\hline $\begin{array}{l}\text { Williams et } \\
\text { al., 2005b } \\
\text { S1 }\end{array}$ & 31 & ADOS, ADI-R & $\begin{array}{l}26.58 \\
(8.68)\end{array}$ & $\begin{array}{l}108.65 \\
(16.75)\end{array}$ & 25 & $\begin{array}{l}26.76 \\
(9.08)\end{array}$ & $\begin{array}{l}109.76 \\
(11.63)\end{array}$ & $\begin{array}{l}\text { N-Back Letter } \\
\text { task, } \\
\text { Letter-Number } \\
\text { Sequencing, } \\
\text { Spatial Span } \\
\text { subtest }^{*}\end{array}$ & $\begin{array}{l}\text { Verbal } \\
\text { verbal } \\
\text { spatial }\end{array}$ & $\begin{array}{l}\text { manipulation } \\
\text { manipulation }\end{array}$ & $\begin{array}{l}\text { Individuals with autism, } \\
\text { regardless of age, exhibited } \\
\text { intact verbal working } \\
\text { memory and impaired } \\
\text { spatial working memory in } \\
\text { two experiments. }\end{array}$ & $\begin{array}{l}\text { The control group was } \\
\text { matched for age and } \\
\text { cognition. }\end{array}$ \\
\hline $\begin{array}{l}\text { Williams et } \\
\text { al., 2005b }\end{array}$ & 24 & ADOS, ADI-R & $\begin{array}{l}11.75 \\
(2.36)\end{array}$ & $\begin{array}{l}109.67 \\
(16.07)\end{array}$ & 44 & $\begin{array}{l}12.39 \\
(2.16)\end{array}$ & $\begin{array}{l}109.95 \\
(10.66)\end{array}$ & $\begin{array}{l}\text { N-Back Letter } \\
\text { task, }\end{array}$ & verbal & manipulation & & \\
\hline S2 & & & & & & & & $\begin{array}{l}\text { Number/Letter } \\
\text { Memory } \\
\text { subtest, } \\
\text { Finger Windows } \\
\text { subtest }\end{array}$ & spatial & $\begin{array}{l}\text { maintenance } \\
\text { maintenance }\end{array}$ & & \\
\hline $\begin{array}{l}\text { Williams et } \\
\text { al., } 2006\end{array}$ & 38 & ADI, ADOS & $\begin{array}{l}11.68 \\
(2.46)\end{array}$ & $\begin{array}{l}103.82 \\
(14.29)\end{array}$ & 38 & $\begin{array}{l}12.16 \\
(2.19)\end{array}$ & $\begin{array}{l}107.18 \\
(9.37)\end{array}$ & $\begin{array}{l}\text { Digit Span", } \\
\text { Number/Letter } \\
\text { Memory } \\
\text { subtest, } \\
\text { Finger Windows } \\
\text { subtest }\end{array}$ & $\begin{array}{l}\text { verbal } \\
\text { verbal } \\
\text { spatial }\end{array}$ & $\begin{array}{l}\text { maintenance } \\
\text { maintenance }\end{array}$ & $\begin{array}{l}\text { Children with autism were } \\
\text { characterized by relatively } \\
\text { intact verbal working } \\
\text { memory and poor spatial } \\
\text { working memory. }\end{array}$ & $\begin{array}{l}\text { The two participant groups } \\
\text { did not significantly differ with } \\
\text { respect to age, Full Scale IQ, } \\
\text { race, or socioeconomic status. }\end{array}$ \\
\hline $\begin{array}{l}\text { Yi et al., } \\
2014\end{array}$ & 25 & DSM-IV & $\begin{array}{l}7.66 \\
(1.56)\end{array}$ & None & 25 & $\begin{array}{l}7.68 \\
(1.72)\end{array}$ & $\begin{array}{l}91.12 \\
(14.04)\end{array}$ & Block Recall task & spatial & maintenance & $\begin{array}{l}\text { Children with ASD } \\
\text { performed significantly } \\
\text { more poorly on the Block } \\
\text { Recall Task compared with } \\
\text { participants in both the } \\
\text { age-matched typically } \\
\text { developing group and the }\end{array}$ & $\begin{array}{l}\text { The typically developing } \\
\text { control group was matched } \\
\text { with the ASD group on } \\
\text { chronological age. }\end{array}$ \\
\hline
\end{tabular}




\begin{tabular}{|c|c|c|c|c|c|c|c|c|c|c|c|c|}
\hline & & & & & & & & & & & $\begin{array}{l}\text { ability-matched typically } \\
\text { developing group. }\end{array}$ & \\
\hline $\begin{array}{l}\text { Zinke et } \\
\text { al., } 2010\end{array}$ & 15 & $\begin{array}{l}\text { ICD-10, ADI-R, } \\
\text { ADOS }\end{array}$ & $\begin{array}{l}9.0 \\
(1.5)\end{array}$ & $\begin{array}{l}96.4 \\
(14.5)\end{array}$ & 17 & $\begin{array}{l}9.8 \\
(1.7)\end{array}$ & none & $\begin{array}{l}\text { Digit Span } \\
\text { Forward task, } \\
\text { Corsi-Block- } \\
\text { Tapping } \\
\text { Forward task }\end{array}$ & $\begin{array}{l}\text { verbal } \\
\text { spatial }\end{array}$ & $\begin{array}{l}\text { maintenance } \\
\text { maintenance }\end{array}$ & $\begin{array}{l}\text { The autism group exhibited } \\
\text { intact verbal short-term } \\
\text { memory (Digit Span) and a } \\
\text { poorer performance of } \\
\text { visuospatial short-term } \\
\text { memory. }\end{array}$ & $\begin{array}{l}\text { The two groups were matched } \\
\text { for chronological age. }\end{array}$ \\
\hline
\end{tabular}

Notes: ${ }^{\#}$ The author only reported the total score of the two tasks between the two groups.

* The digit span test comprises two subtests, digits forward and digits backward; however, only the total score was provided in the paper.

Manipulation denotes maintenance plus manipulation.

CANTAB represents the abbreviation for the Cambridge Neuropsychological Test Automatic Battery.

exp1, exp2 and exp3 indicate that there were three experiments in one study.

S1 and $\mathrm{S} 2$ indicate that two independent samples (children \& adults) were included in one study. 


\section{Table 2}

Effect of diagnostic criteria on WM impairment in individuals with ASD.

\begin{tabular}{|c|c|c|c|c|c|c|c|c|c|}
\hline & $K$ & $\begin{array}{c}N \\
\text { Patient } \\
\text { Group }\end{array}$ & $\begin{array}{c}N \\
\text { Control } \\
\text { Group }\end{array}$ & $d$ & $Z$ & $P$ & $95 \% \mathrm{Cl}$ & $Q$ & $p$ \\
\hline ADI/ADOS & 9 & 213 & 244 & -0.38 & -2.93 & 0.003 & $(-0.63,-0.13)$ & 13.73 & 0.089 \\
\hline ADI/ADOS, DSM/ICD & 8 & 295 & 298 & -0.68 & -6.39 & $<0.001$ & $(-0.89,-0.47)$ & 10.50 & 0.162 \\
\hline DSM/ICD & 10 & 217 & 244 & -0.47 & -2.41 & 0.016 & $(-0.86,-0.09)$ & 35.43 & $<0.001$ \\
\hline
\end{tabular}

Note: $K=$ number of studies; $N=$ number of participants; $C l=$ confidence interval. 


\section{Table 3}

Effect of WM type on WM impairment in individuals with ASD.

\begin{tabular}{lcccccccccc}
\hline & $K$ & $\begin{array}{c}N \text { Patient } \\
\text { Group }\end{array}$ & $\begin{array}{c}\text { N Control } \\
\text { Group }\end{array}$ & $d$ & $Z$ & $P$ & $95 \% C l$ & $Q$ & $p$ \\
\hline Spatial WM & 20 & 633 & 720 & -0.72 & -7.55 & $<0.001$ & $(-0.91,-0.54)$ & 49.06 & $<0.001$ \\
Verbal WM & 19 & 437 & 478 & -0.44 & -4.32 & $<0.001$ & $(-0.64,-0.24)$ & 36.74 & 0.006 \\
\hline
\end{tabular}

Note: $K=$ number of studies; $N=$ number of participants; $C l=$ confidence interval. 


\section{Table 4}

Effect of component of cognitive processing on WM impairment in individuals with ASD.

\begin{tabular}{lcccccccccc}
\hline & $K$ & $\begin{array}{c}N \text { Patient } \\
\text { Group }\end{array}$ & $\begin{array}{c}N \text { Control } \\
\text { Group }\end{array}$ & $d$ & $Z$ & $p$ & $95 \% C l$ & $Q$ & $p$ \\
\hline Manipulation & 18 & 413 & 556 & -0.53 & -5.30 & $<0.001$ & $(-0.73,-0.33)$ & 39.96 & 0.001 \\
Maintenance & 17 & 439 & 469 & -0.62 & -4.89 & $<0.001$ & $(-0.87,-0.37)$ & 51.27 & $<0.001$ \\
\hline
\end{tabular}

Note: $K=$ number of studies; $N=$ number of participants; $C l=$ confidence interval. 
Table 5

Effect of cognitive load on WM impairment in individuals with ASD.

\begin{tabular}{lcccccccccc}
\hline & $K$ & $\begin{array}{c}\text { N Patient } \\
\text { Group }\end{array}$ & $\begin{array}{c}\text { N Control } \\
\text { Group }\end{array}$ & $d$ & $Z$ & $P$ & $95 \% \mathrm{Cl}$ & $Q$ & $p$ \\
\hline 1-back & 4 & 78 & 109 & -0.84 & -1.90 & 0.057 & $(-1.71,-0.03)$ & 20.73 & $<0.001$ \\
2-back & 4 & 78 & 109 & -0.83 & -2.24 & 0.025 & $(-1.55,-0.11)$ & 14.63 & 0.002 \\
\hline
\end{tabular}

Note: $K=$ number of studies; $N=$ number of participants; $C l=$ confidence interval. 


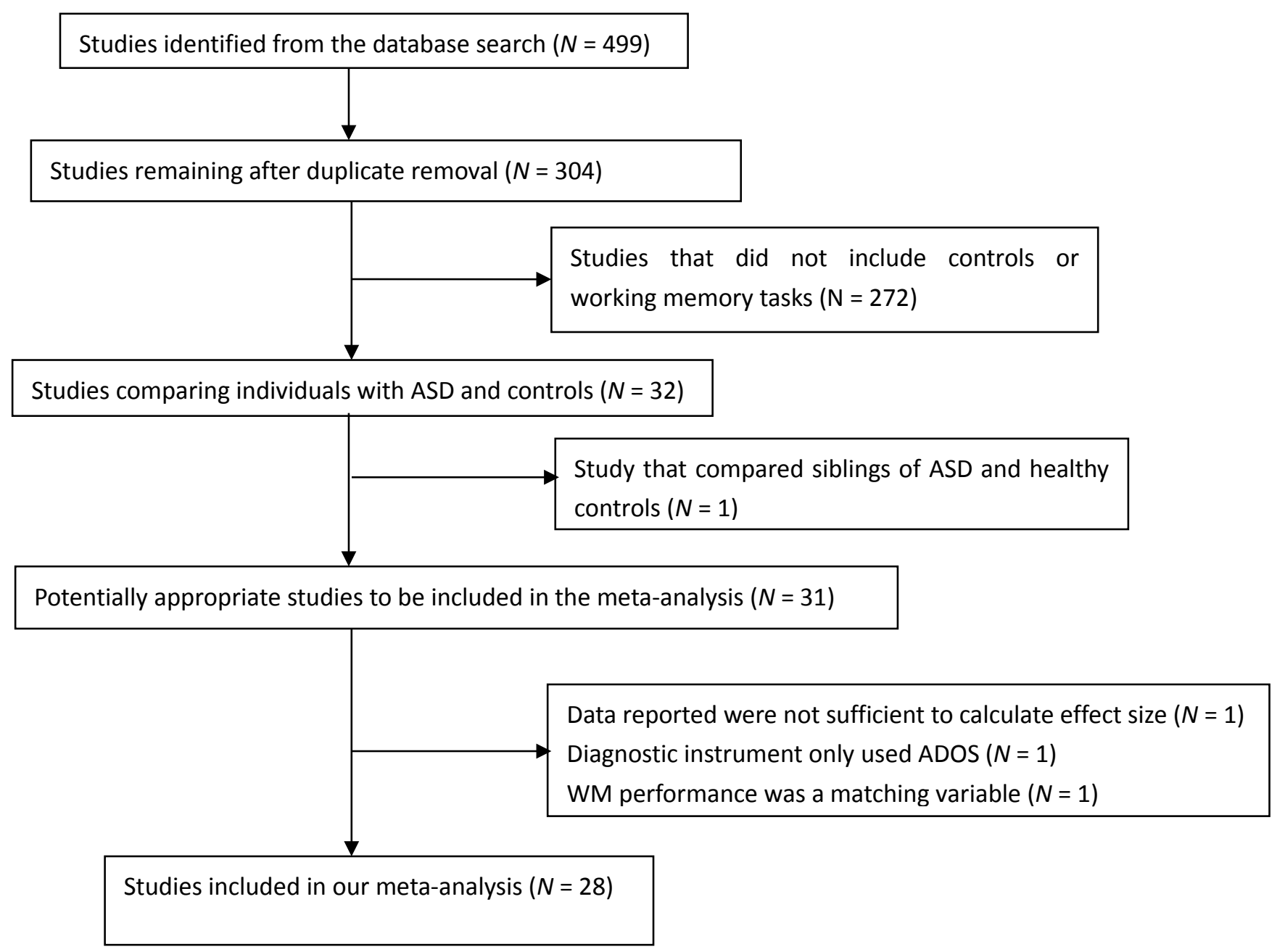

Figure 1. Flow diagram of the selection process of the articles included in the meta-analysis. 


\begin{tabular}{ll|} 
ADI/ADOS & Geurts et al.,2004 \\
& Goldberg et al.,2005 \\
& Koshino et al.,2008 \\
& Landa et al.,2005 \\
& Lopez et al.,2005 \\
& Williams et al.,2005bS1 \\
& Williams et al.,2005bS2 \\
& Williams et al., 2006 \\
& Zinke et al.,2010 \\
Random Effects Model \\
Ham et al.,2011 \\
Joseph et al.,2005a \\
Joseph et al.,2005b \\
Sachse et al.,2013 \\
Steele et al., 2007 \\
Verte et al.,2005 \\
Verte et al.,2006 \\
Williams et al., 2005a \\
Random Effects Model \\
Crane et al.,2011 \\
Cui et al., 2010 \\
Garcia-Villamisar et al.,2002 \\
Gonzalez-Gadea et al.,2013 \\
Happe et al.,2006 \\
Nakahachi et al.,2006 \\
Nydén et al.,1999 \\
Russell et al.,1996exp1 \\
Russell et al.,1996exp2 \\
Yi et al.,2014 \\
Random Effects Model \\
\end{tabular}

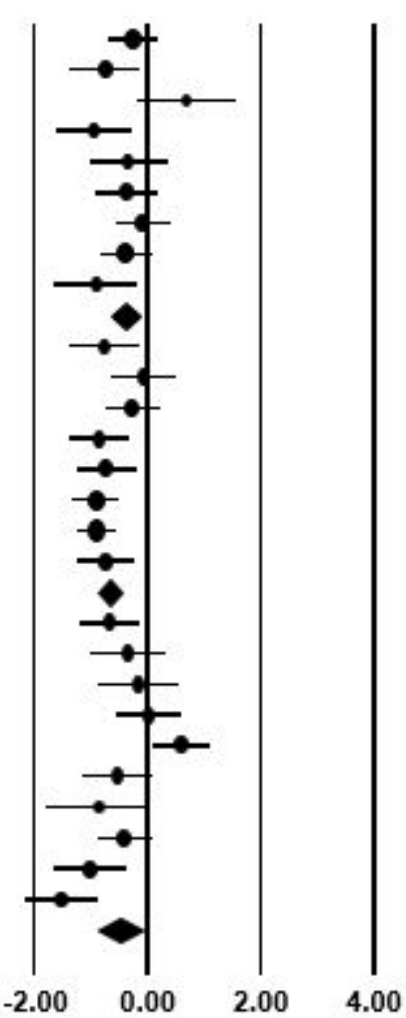

Standard Difference

Figure 2. Forest plot for the results of the diagnostic criteria on WM impairment in individuals with ASD. The plot displays the effect size (standard difference) with the associated $95 \%$ confidence intervals. The overall effect size is calculated using a random effects model. 


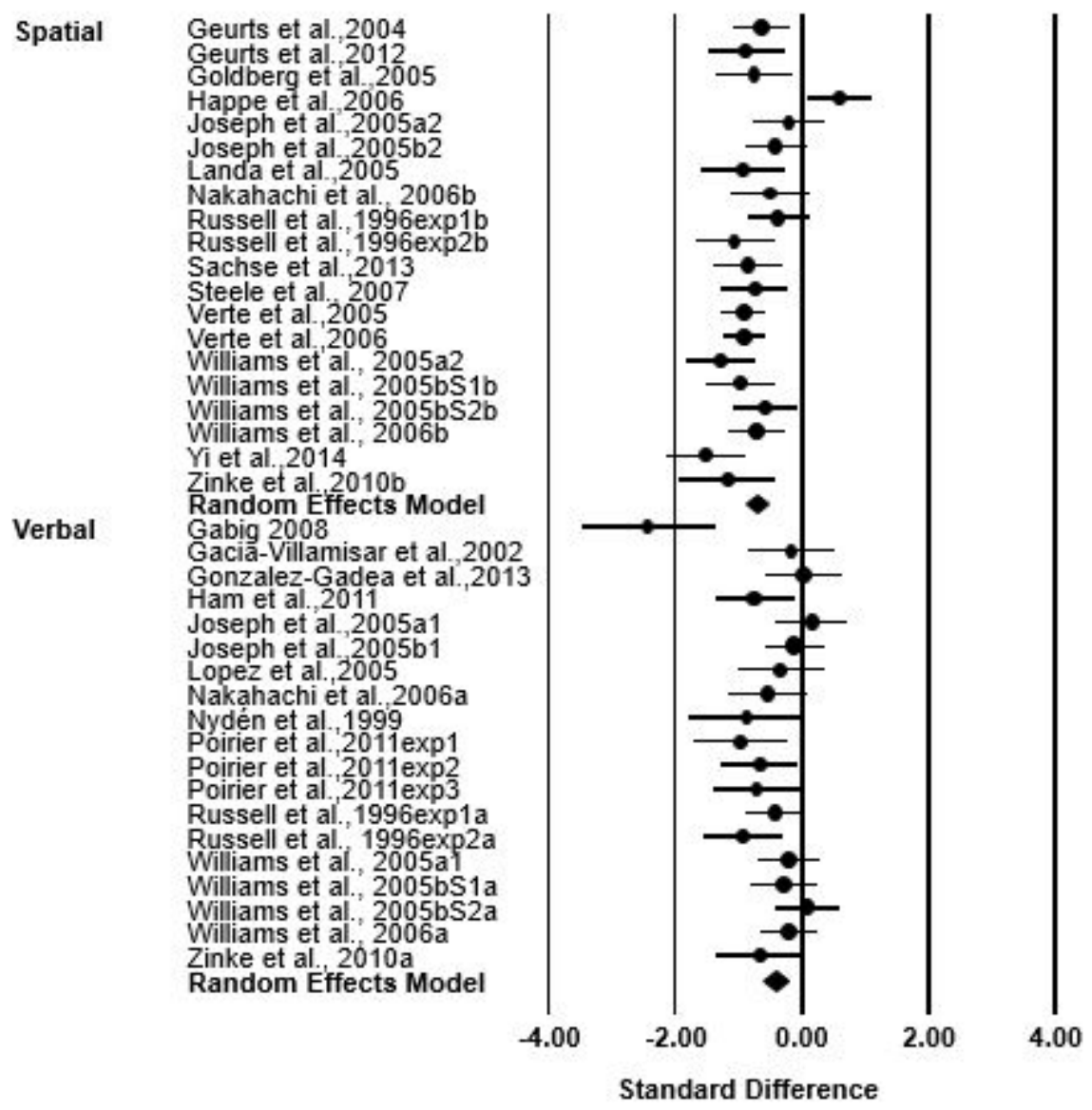

Figure 3. Forest plot for the results of WM types on WM impairment in individuals with ASD. The plot displays the effect size (standard difference) with the associated $95 \%$ confidence intervals. The overall effect size is calculated using a random effects model. 


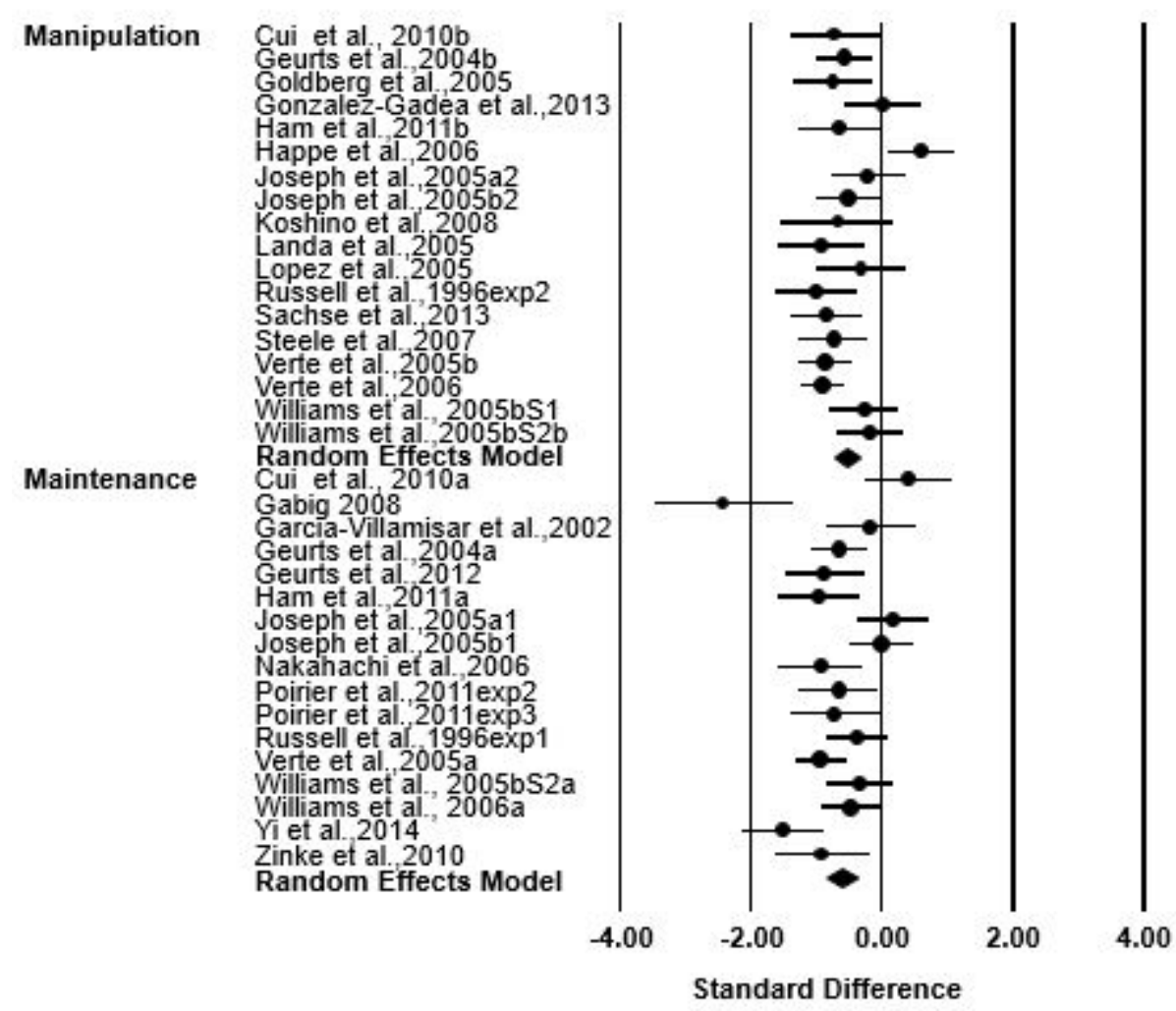

Figure 4. Forest plot for the results of the component of cognitive processing on WM impairment in individuals with ASD. The plot displays the effect size (standard difference) with the associated $95 \%$ confidence intervals. The overall effect size is calculated using a random effects model. 
1-back

Cui et al., 2010

Koshino et al.,2008

Williams et al., 2005bS1

Williams et al., 2005bS2

2-back

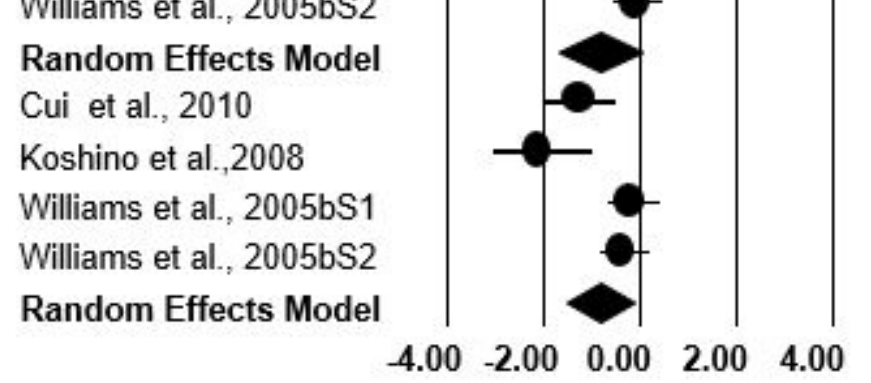

Standard Difference

Figure 5. Forest plot for the results of the $n$-back task in individuals with ASD. The plot displays the effect size (standard difference) with the associated 95\% confidence intervals. The overall effect size is calculated using a random effects model. 